\title{
Bankacılık Sektöründe Hizmet Pazarlaması Algısının Çeşitli Değişkenler Açısından İncelenmesi
}

Filiz ASLAN ÇETIN*

Nazan KORUCUK**

Öz

$\mathrm{Bu}$ çalışmada bankacılık sektöründe hizmet pazarlaması algısının tüketiciler açısından gösterdiği değişikliklerin incelenmesi amaçlanmıştır. Araştırmada nicel araştırma yöntemlerinden tarama modeli kullanılmıştır. Bu çalışmanın evreni 2019 yılında Kars ili Merkez ilçede yaşayan katılımcılardan oluşmaktadır. Örneklemi ise ilgili evrenden seçilen basit seçkisiz örnekleme yöntemi ile belirlenen 523 kişiden oluşmaktadır. Çalışmada kullanılan veri toplama aracının geçerliliği ve güvenirliği tekrar test edilerek, geçerli ve güvenilir olduğu sonucuna ulaşılmıştır. Normallik varsayımlarının karşılanıp karşılanmadığına ilişkin analizler sonucunda verilerin normal dağılım gösterdiği sonucuna ulaşılmıştır. Bu bulgular 1şığında verilerin parametrik teknikler ile analiz edilmesine olanak veren varsayımların karşılandığı sonunca ulaşılmıştır. Bu sebeple araştırma verileri frekans analizi, bağımsız örneklem t-testi ve tek yönlü varyans analizi (ANOVA) ile analiz edilmiştir. Araştırma sonucunda tüketicilerin bankacılık sektöründeki hizmet pazarlaması algısının çeşitli değişkenler açısından farklılaştığı tespit edilmiştir. Araştırma sonuçları doğrultusunda çeşitli öneriler geliştirilmiştir.

Anahtar Kelimeler: Hizmet Pazarlaması, Bankacılık Sektörü, Alg1.

\section{Analysis of Service Marketing Perception in Banking Sector in Terms of Various Variables}

\begin{abstract}
In this study, it is aimed to examine the changes in the perception of service marketing in the banking sector for consumers. In the research, survey model which is one of the quantitative research methods was used. The population of this study consists of participants living in the central district of Kars in 2019. The sample consisted of 523 individuals selected by simple random sampling method selected from the population. The validity and reliability of the data collection tool used in the study were re-tested and found to be valid and reliable. As a result of the analyzes on whether the normality assumptions were met, it was concluded that the data showed normal distribution. In the light of these findings, it is concluded that the assumptions that allow the analysis of the data with parametric techniques are met. Therefore, the research data were analyzed by frequency analysis, independent sample t-test and one-way analysis of variance (ANOVA). As a result of the research, it was determined that the perception of service marketing of consumers in the banking sector differed in terms of various variables. Various suggestions have been developed in line with the results of the research.
\end{abstract}

Keywords: Service Marketing, Banking Sector, Perception.

Received/Geliş: 10.02 .2020

Accepted/Kabul: 27.11.2019

* Bu çalışma için, 05.05.2020 tarihli başvuru ile Kafkas Üniversitesi Sosyal ve Beşerî Bilimler Etik Kurulundan 22.05.2020 tarih ve 2020/09 sayılı etik kurul izni alınmıştır.

\footnotetext{
* Dr. Öğr. Üyesi, Kafkas Üniversitesi İktisadi ve İdari Bilimler Fakültesi, filizaslan79@gmail.com, D/0000-00028210-799X.

** Doktora Öğrencisi, Kafkas Üniversitesi Sosyal Bilimler Enstitüsü, nazan3634@gmail.com, (D/0000-0003-22080657.

(Makale türü: Araştırma Makalesi)
} 


\section{Giriş}

Sanayi Devrimi öncesinde hizmetler günlük hayatı devam ettirecek şekilde ortaya çıkarken, günümüzde ekonomik ve sosyal hayatı devam ettirecek (eğitim, sağlık, ulaşım, istihdam, hukuk vb.) şekilde faaliyet göstermektedirler (Güven \& Çelik, 2007). Bu açıklamalar doğrultusunda hizmet kavramı incelendiğinde çeşitli tanımlara yer verilebilir. Hizmet, tüketicilerin ihtiyaçlarının tatmin edilmesiyle meydana gelen maddi olmayan ürünlerdir (Kuriloff, Hemphill \& Cloud, 1993). Bununla birlikte hizmet; zaman, yer, biçim ve psikolojik faydalar sağlayan ekonomik faaliyetler şeklinde de tanımlamak mümkündür (Gözlü, 1995). Başka bir tanımda ise hizmet, "Tüketicilerin ilişkisi olmaksızın satın aldıkları faydalar" olarak tanımlanmaktadır (Mucuk, 1994). Hizmet kavramından yola çıkarak hizmet pazarlaması ise, satış1 gerçekleştirilecek olan tüm mallara bağlı olarak ya da olmayarak önerilen çalışma, fayda ve memnuniyetler bütünü olarak tanımlanabilir (Kantaroğlu, 2018). Hizmet pazarlamasındaki işletmeler, hizmetlerini sundukları müşterileri üzerinde memnuniyet sağlayarak hem müşteri sadakati oluşturabilir hem de işletmelerinin uzun süre ayakta kalmalarına olanak sağlayabilirler. Bundan dolayı da hizmet pazarlamasında sadece hizmetin yapımı ve pazarlaması değil aynı zamanda hizmet yapım süreci de önem kazanmaktadır (Yücel, Yücel \& Atlı, 2012; Yüksel \& Mermod, 2004). Günümüzde rekabet düzeyinin artmasıyla birlikte işletmelerin hizmet sektöründe üstünlük sağlayabilmeleri için hizmet pazarlamasını benimseyerek uygulamaları zorunlu hale gelmiştir. Bundan dolayı hizmet işletmelerinin hizmet pazarlamasına önem vermeleri gerekmektedir (Koç, 2018; Yücel vd., 2012).

Hizmet pazarlamasında eğitim, sağlık, turizm, bankacılık vb. sektörlerinin önemli bir yeri vardır. Bu çalışmada bankacılık sektöründe hizmet pazarlaması algısı çeşitli değişkenler açısından incelenmiştir. Araştırmaya konu olan banka, "kredi ve para alanlarında çeşitli işlemleri gerçekleştiren ve biçimlendiren özel ve kamu kişileri ile kuruluşlar arasındaki her çeşit ihtiyaçları giderme faaliyetlerini temel konu olarak seçen bir ekonomik unsurdur” şeklinde tanımlanabilir (Kayalı \& Yüksel, 2012). Günümüzde bankalar sadece kredi ve mevduat işlemleri yapmamaktadırlar. Bankalar aynı zamanda finansal işlemler, menkul kıymet alım ve satım işlemleri, kiralık kasa, kredi kartı işlemleri, maaş işlemleri, iç ve dış ticaret faaliyetlerinde aracılık işlemleri vb. birçok alanda faaliyet göstermektedirler (Yetiz, 2016). Bankacılık sektörünün ülke ekonomisi içinde çok önemli bir yeri vardır. Ülke genelindeki finansal güç bankaların güçlü olmasına ve uzun dönemli ekonomik istikrarın sağlanmasında da bankaların rolü çok büyüktür. Bankacılık sektörü, ülke içerisindeki hızlı ekonomik büyüme ve gelişmenin gerçekleştirilmesi için önemli bir araçtır (Kantaroğlu, 2018; Yetiz, 2009).

Diğer ülkeler gibi Türkiye'de de sanayinin kurulmasında ve gelişmesinde, ticari hayatta işlerin daha kolay ve güvenli bir şekilde yürütülmesinde, kurumsal ihtiyaçların yanı sıra, 
bireylerin ödeme, kredi, mevduat, transfer vb. birçok işlemlerini yürütmelerinde bankaların rolü oldukça önemli hale gelmiştir (Sümer, 2016; Yetiz, 2016). Türk bankaları da son derece modern ve güvenli bir görüntüye sahiptirler. Güçlü ve başarılı üst kurullarıyla önemli derecede sermaye yapısına sahip olan Türk Bankacılık Sektörü her gün daha da büyümektedir (Özdemir, 2010). 2019 y1lı itibariyle Türkiye'de gruplar bazında toplamda 47 adet banka faaliyet göstermektedir. Bunlardan 3 tanesi Kamusal Sermayeli mevduat bankaları, 9 tanesi Özel Sermayeli Mevduat Bankaları, 1 tanesi Tasarruf Mevduatı Sigorta Fonuna Devredilen Bankalar, 21 tanesi Yabancı Sermayeli Bankalar, 13 tanesi de Kalkınma ve Yatırım Bankaları grubunda bulunmaktadır. Bu bankalar yurt içi ve yurt dişında toplamda 10.272 adet şubeleriyle aktif halde görev yapmaktadırlar (www.tbb.org.tr, 2019; www.bddk.org.tr, 2019; www.muhasebenews.com, 2019). Öte yandan bankacılık sektörünün daha sağlıklı bir yapıya sahip olması, ekonominin gelişimi açısından da oldukça önemlidir. Finansal sistem içerisinde bankacılık sektörünün güçlü olması, ekonomik büyüme açısından oldukça faydalı olacaktır. Finansal açıdan yaşanacak zorluklar ekonomik aktivitenin önemli derecede azalmasına sebep olabilir. İşte bu sebeple Türkiye'nin ekonomisinde bozulmaların olmaması, potansiyelini artırarak hızla büyümesi için bankacılık sektörünün sağlamlığının korunmasının büyük önem taşıdığg söylenebilir. Türk bankacılık sektörünün finansal sistemde önemli bir yere sahip olması nedeniyle ekonomik kalkınma ve büyüme de kritik rol üstlenmektedir (www.assets.kpmg.com.tr, 2019).

\section{Araştırmanın Amacı ve Önemi}

$\mathrm{Bu}$ araştırmada bankacılık sektöründe hizmet pazarlaması algısının tüketiciler açısından gösterdiği değişikliklerin incelenmesi amaçlanmıştır. Her alanda olduğu gibi bankacılık sektöründe de piyasada tutunma ve kar elde etme müşteri devamlılığı da önemli bir faktör haline gelmiştir. Müşteri devamlılığını da müşteri memnuniyeti ve kalite algısı ile gerçekleşmektedir. $\mathrm{Bu}$ yüzden araştırmada müşteri hizmet kalitesi algısı ölçülerek varılması gereken nokta, müşterinin sektörden beklentilerinin neler olduğunu kavramaya çalışmaktır. Bu araştırma ilgili alan yazına katkı sağlayacağı açısından önemlidir. Ayrıca Kars ilinde bankacılık sektöründe hizmet pazarlaması algısına yönelik tüketici algısı üzerine yapılmış herhangi bir çalışmaya rastlanmamıştır. Bundan dolayı da bu çalışma Kars ilindeki tüketicilerin bankacılık sektöründe hizmet kalitesi algısına bakış açılarının ölçülmesi açısından önemlidir.

\section{Yöntem}

\section{Araştırmanın Yöntemi, Model ve Hipotezleri}

Tarafsızlığın ön planda olduğu ve sonuçların sayısallaştırılarak ifade edildiği (McMillan \& Schumacher, 2014) nicel desenli bu çalışmada tarama modeli tercih edilmiştir. Tarama modeli ilgi, tuttum ve alg1 gibi özelliklerin açıklanabilmesi için çok sayıda bireyden geçerliği ve güvenirliği sınanmış ölçme araçları ile veri toplanması şeklinde gerçekleştirilen bir araştırma 
türüdür (Büyüköztürk, Çakmak, Akgün, Karadeniz \& Demirel, 2017; Fraenkel \& Wallen, 2006). $\mathrm{Bu}$ çalışmada da kalabalık bir kitleden örneklem alma yoluna gidilerek standartlaştırılmış veri toplama aracı ile veri elde edilmiş, veriler çözümlenmiş, araştırma hipotezleri sınanmış ve nihayetinde araştırma sonuçlarına ulaşılmıştır. Bu araştırmaya ait model Şekil 1'de gösterilmektedir.
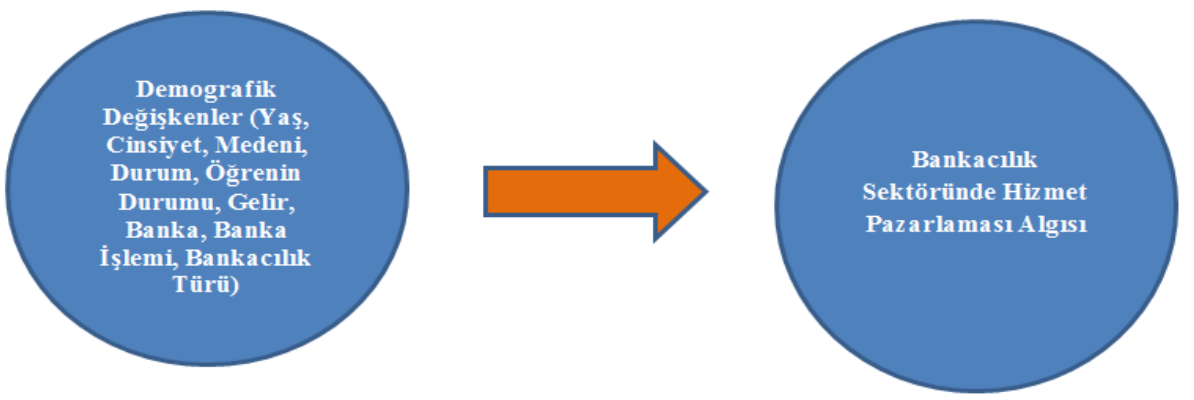

Şekil 1: Araştırma Modeli

Şekil 1'de gösterildiği gibi bu çalışmada tüketicilerin bankacılık sektöründe hizmet pazarlaması algısının tüketicilere ait demografik özelliklere göre farklılaşma durumları incelenmiştir. Bunun yanında araştırma problemi "Tüketicilerin bankacılık sektöründeki hizmet pazarlaması algıları ne düzeydedir?” şeklinde belirlenmiştir. Bu çalışmada araştırma sorusuna ek olarak; bir bilimsel araştırmada ulaş1labilecek muhtemel sonuçlar doğrultusunda ortaya atılan tahmin olarak tanımlanabilen (Punch, 2014) araştırma hipotezleri de geliştirilmiştir. Bu amaçla hazırlanan araştırma hipotezleri;

$\mathrm{H}_{1}$ : Bankac1lık sektöründe hizmet pazarlaması algısı tüketicilerin cinsiyetlerine göre farklılaşmaktadır.

$\mathrm{H}_{2}$ : Bankacılık sektöründe hizmet pazarlamas1 algısı tüketicilerin medeni durumlarına göre farklılaşmaktadır.

$\mathrm{H}_{3}$ : Bankacılık sektöründe hizmet pazarlaması algısı tüketicilerin yaşlarına göre farklılaşmaktadır.

$\mathrm{H}_{4}$ : Bankacılık sektöründe hizmet pazarlaması algısı tüketicilerin öğrenim durumlarına göre farklılaşmaktadır.

$\mathrm{H}_{5}$ : Bankacılık sektöründe hizmet pazarlaması algısı tüketicilerin gelir düzeylerine göre farklılaşmaktadır.

$\mathrm{H}_{6}$ : Bankacılık sektöründe hizmet pazarlaması algısı tüketicilerin en çok işlem yaptıkları bankaya göre farklılaşmaktadır.

$\mathrm{H}_{7}$ : Bankacılık sektöründe hizmet pazarlaması algısı tüketicilerin banka ile en çok yaptıkları işlem türüne göre farklılaşmaktadır. 
$\mathrm{H}_{8}$ : Bankacılık sektöründe hizmet pazarlaması algısı tüketicilerin en çok kullandıkları bankacılık türüne göre farklılaşmaktadır.

\section{Evren ve Örneklem}

Bu çalışmada evren 2019 yılında Kars'ta ikamet eden 115.891 (2018 verileri www.karsnufusu.gov.tr) bireyden meydana gelmektedir. Evrenin tamamına ulaşmanın mümkün olmayacağından dolayı örneklem alma yoluna gidilmiştir. Çalışmada kullanılan örnekleme yöntemi basit seçkisiz örneklemedir. Basit seçkisiz örnekleme seçkili biçimde hareket edilen örnekleme yöntemlerine oranla evreni daha güçlü temsil yeteneğine sahiptir (Cristensen, Johnson \& Turner, 2015; Gliner, Morgan \& Leech, 2015). Örneklem hesaplanmasında \%95 güvenirlik ve \%5'lik hata payı ile ulaşılması gereken en az örneklem büyüklüğü 383 olarak belirlenmiştir (https://www.surveysystem.com). Bu çalışmada ise 523 kişiye ulaşılmıştır. Tablo 1'de örnekleme ait özellikler gösterilmektedir.

Tablo 1: Örnekleme Ait Özellikler

\begin{tabular}{|c|c|c|c|}
\hline Değişken & & n & $\%$ \\
\hline \multirow{2}{*}{ Cinsiyet } & Kadın & 212 & 40,5 \\
\hline & Erkek & 311 & 59,5 \\
\hline \multirow{2}{*}{ Medeni Durum } & Evli & 229 & 43,8 \\
\hline & Bekar & 294 & 56,2 \\
\hline \multirow{6}{*}{ Yaş } & $18-25$ & 99 & 18,9 \\
\hline & $26-33$ & 113 & 21,6 \\
\hline & $34-41$ & 86 & 16,4 \\
\hline & $41-48$ & 51 & 9,8 \\
\hline & $48-55$ & 81 & 15,5 \\
\hline & 55 ve üzeri & 93 & 17,8 \\
\hline \multirow{5}{*}{ Öğrenim Durumu } & İlköğretim & 57 & 10,9 \\
\hline & Ortaöğretim & 49 & 9,4 \\
\hline & Önlisans & 211 & 40,3 \\
\hline & Lisans & 134 & 25,6 \\
\hline & Lisanüstü & 72 & 13,8 \\
\hline \multirow{5}{*}{ Gelir } & $0-1500$ & 219 & 41,9 \\
\hline & $1501-3000$ & 139 & 26,6 \\
\hline & $3001-4500$ & 67 & 12,8 \\
\hline & $4501-6000$ & 46 & 8,8 \\
\hline & $6001-7500$ & 52 & 9,9 \\
\hline \multirow{2}{*}{ En Çok İşlem Yapılan Banka } & Kamu Bankaları & 325 & 62,1 \\
\hline & Özel Bankaları & 198 & 37,9 \\
\hline \multirow{5}{*}{ En Fazla Yapılan İşlem } & Para Yatırma Çekme & 314 & 60,0 \\
\hline & Transfer & 46 & 8,8 \\
\hline & Kredi Kartı İșlemleri & 44 & 8,4 \\
\hline & Kredi Kullanımı & 60 & 11,5 \\
\hline & Maaș İşlemleri & 59 & 11,3 \\
\hline \multirow{2}{*}{ Bankacılık Türü } & Şube Bankacılı̆̆1 & 277 & 53,0 \\
\hline & İnternet Bankacılı̆̆ & 246 & 47,0 \\
\hline
\end{tabular}

\section{Veri Toplama Araci}

Çalışmada bankacılık Sektöründe Hizmet Pazarlaması Algısının Tüketiciler Açısından Gösterdiği Değişikliklerin belirlenebilmesi için “Kişisel Bilgi Formu” ile "Bankacılık Sektöründe Hizmet Pazarlamasına Ait Algı Ölçeği (BSHPAAÖ)” kullanılmıştır. Kişisel bilgi formu 8 sorudan oluşmaktadır. Bu sorular ile tüketicilerin cinsiyetleri, medeni durumları, yaşları, öğrenim 
durumları, gelir düzeyleri, en çok tercih ettikleri banka ve bankacılık işlemi ile bankacılık türünün belirlenmesi amaçlanmıştır. BSHPAAÖ Mujic \& Legcevic (2006) tarafından geliştirilmiş ve Savaş ve Kesmez (2014) tarafindan Türkçe 'ye uyarlanmıştır. BSHPAAÖ 5 alt boyut "Fiziksel Özellikler (4 madde)=1, 2, 3, 4; Güvenirlik (5 madde $)=5,6,7,8$, 9; Heveslilik (4 madde $)=10,11$, 12, 13; Güven (4 madde) $=14,15,16,17$; Empati (4 madde) $=18,19,20,21$ " ve 21 ifadeden oluşmaktadır. Olumsuz maddenin bunmadığı ölçek 5'li likert tipindedir. Ölçek derecelendirilmesi ve puan aralıkları Tablo 2'de gösterilmektedir.

Tablo 2: Ölçeğe Ait Puanlar ve Karşılıkları (Sullivan \& Artino, 2013).

\begin{tabular}{lccc}
\hline Seçenek Puanları & Puanlar & Anlamı & Aralığın Değeri \\
\hline Kesinlikle Katılmıorum & $1.00-1.80$ & Çok Düşük Düzey & "Çok Olumsuz" puan aralığı \\
Katılmıyorum & $1.81-2.60$ & Düşük Düzey & "Olumsuz" puan aralığı \\
Kısmen Katılıyorum & $2.61-3.40$ & Orta Düzey & "Orta" puan aralığı \\
Katılıyorum & $3.41-4.20$ & Yüksek Düzey & "Olumlu” puan aralığı \\
Kesinlikle Katılıyorum & $4.21-5.00$ & Çok Yüksek Düzey & "Çok Olumlu" puan aralığı \\
\hline
\end{tabular}

Verilerin güvenirliğinin belirlenebilmesi için hesaplanan Cronbach-Alpha iç tutarlılık katsayısının referans aralıkları " $0.00 \leq \alpha \leq 0.40=$ güvenilir değildir, $0.40 \leq \alpha \leq 0.60=$ düşük güvenilirdir, $0.60 \leq \alpha \leq 0.80=$ oldukça güvenilirdir, $0.80 \leq \alpha \leq 1.00=$ yüksek derecede güvenilirdir" olarak belirlenmiştir (Özdamar, 1997). Diğer taraftan sosyal bilimlerde varyans yükünün \%40 ile \%60 aralığında olması ölçeğin yeterli düzeyde açıklayıcı olduğunu ifade etmektedir (Pallant, 2017). Savaş ve Kesmez (2014) tarafından yapılan güvenirlik çalışmasında ölçeğe ait güvenirlik katsayısı .95 olarak belirlenmiş, 5 faktörlü yapının açıkladığı toplam varyansın \%59 olduğu tespit edilmiştir. Bu değerler ölçeğin güvenilirliğinin yüksek derecede olduğunu gösterirken, açıklanan varyans yükünün yeterli düzeyde olduğunu ortaya koymaktadır. Diğer taraftan Demirtaş (2019) da BSHPAAÖ’nin geçerliği ve güvenirliği sınamış ve ölçeğin geçerli ve güvenilir olduğunu ortaya koymuştur. Bu çalışma kapsamında da BSHPAAÖ'nin faktör yapısının doğrulanabilmesi için doğrulayıcı faktör analizi (DFA) ve güvenirliğinin sınanabilmesi için Cronbach-Alpha iç tutarlılık katsayısı ile iki yarı test tekniğinin yapılması uygun görülmüsstür. DFA'da CFI, NFI ve TLI için $>0.90$ kabul edilebilir değer iken (İlhan \& Çetin, 2014; Taşgın \& Korucuk, 2018); RMR ve RMSEA için ise $<0.05$ son derece iyi bir değer (Yıldırım \& Naktiyok, 2017) olarak kabul edilmektedir. $\chi 2 / s d$ değerinin ise 3'ten küçük olmas1 iyi bir değer iken; 3 ile 5 arasında bir yer alması ise kabul edilebilir bir değer olduğunu göstermektedir. (Kayapal1-Yıldırım \& Ekinci, 2019; Schumacher \& Lomax, 2004; Seçer, 2015). DFA'ya ait diyagram Şekil 2'de gösterilmektedir. 


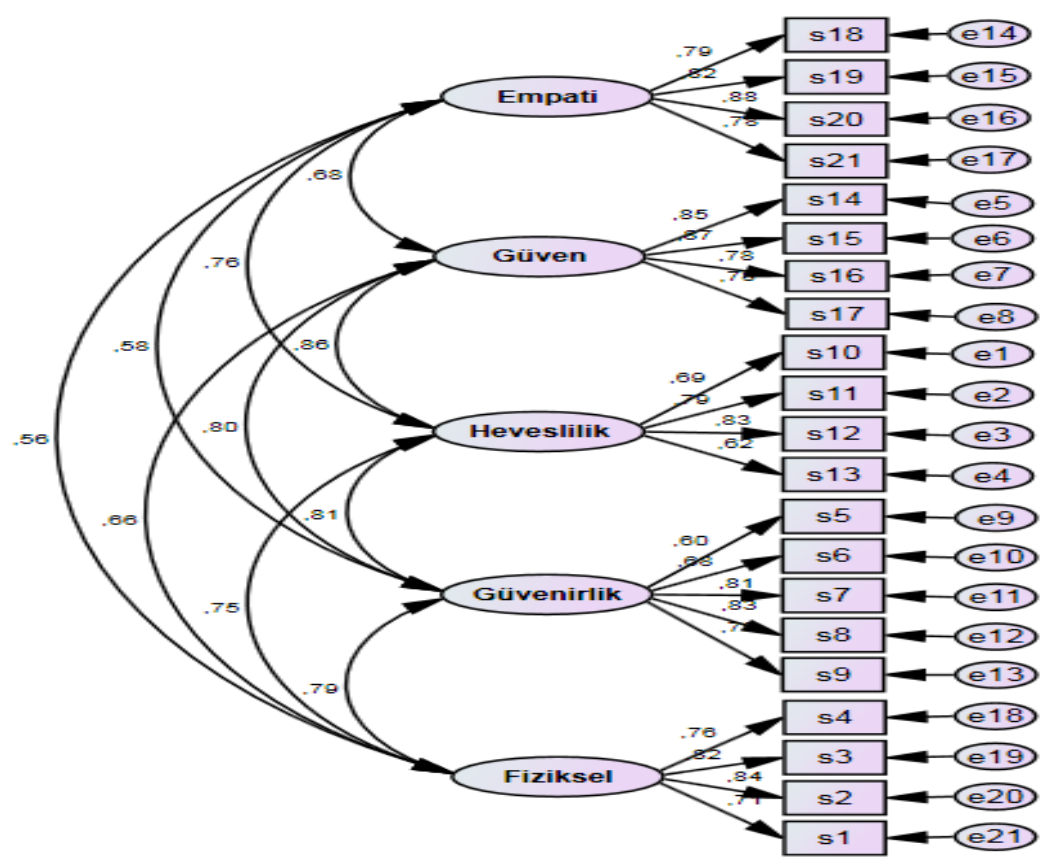

Şekil 2: BSHPAAÖ DFA Diyagramı

Şekil 2'de gösterilen BSHPAAÖ'ne ait madde faktör yükleri Fiziksel boyut: .71, .84, .82, .76 ; Güvenirlik boyutu: .60, .68, .81, .83, .78; Heveslilik boyutu: .69, .79, .83, .62; Güven boyutu: $.85, .87, .78, .78$ : Empati boyutu: $.79, .82, .88, .78$ olarak belirlenmiştir. Madde faktör yüklerinin .50 üzerinde olması maddelerin ölçek için önemli olduğunu gösterdiğinden dolayı (Jöreskop \& Sörbom, 1996), her bir maddenin BSHPAAÖ için önemli olduğu sonucuna varılabilir. Diğer taraftan DFA ile elde edilen uyum indeksleri ile Hooper, Coughan ve Mullen (2008), İlhan ve Çetin (2014) ve Marcoulides ve Schumacher (2001) tarafindan belirtilen uyum indekslerinin referans aralıkları Tablo 3'te gösterilmektedir.

Tablo 3: BSHPAAÖ’ye Ait Uyum İndeksleri

\begin{tabular}{|c|c|c|c|c|}
\hline \multirow{2}{*}{ İndeksler } & \multicolumn{2}{|c|}{ Referans Değeri } & \multirow{2}{*}{ Ölçüm } & \multirow{2}{*}{ Sonuç } \\
\hline & İyi Uyum & Kabul Edilebilir Uyum & & \\
\hline CMIN/DF & $0<\chi^{2} / \mathrm{sd} \leq 3$ & $3<\chi 2 / \mathrm{sd} \leq 5$ & 4,509 & Kabul Edilebilir Uyum \\
\hline TLI &, $95<\mathrm{TLI} \leq 1$ & ,90< TLI $\leq, 94$ & ,90 & Kabul Edilebilir Uyum \\
\hline RMSEA & $0 \leq \mathrm{RMSEA} \leq, 05$ &, $05 \leq \mathrm{RMSEA} \leq, 08$ & ,077 & Kabul Edilebilir Uyum \\
\hline SRMR & $0 \leq \mathrm{SRMR} \leq .05$ & $0.05 \leq \mathrm{SRMR} \leq .10$ &, 09 & Kabul Edilebilir Uyum \\
\hline CFI &, $95<\mathrm{CFI} \leq 1$ &, $90<\mathrm{CFI} \leq, 94$ & ,91 & Kabul Edilebilir Uyum \\
\hline GFI &, $95<\mathrm{GFI} \leq 1$ &, $90<\mathrm{GFI} \leq, 94$ & ,92 & Kabul Edilebilir Uyum \\
\hline AGFI &, $95<\mathrm{AGFI} \leq 1$ &, $90<\mathrm{AGFI} \leq, 94$ & ,93 & Kabul Edilebilir Uyum \\
\hline NFI &, $95<\mathrm{NFI} \leq 1$ &, $90<\mathrm{NFI} \leq, 94$ & ,90 & Kabul Edilebilir Uyum \\
\hline $\mathrm{Sd}$ & & & 179 & \\
\hline
\end{tabular}
indekslerinin de TLI=.90, RMSEA=.077, $\mathrm{SRMR}=.09, \mathrm{CFI}=.91, \mathrm{GFI}=.92, \mathrm{AGFI}=.93, \mathrm{NFI}=.90$ olarak belirlenmiş ve BSHPAAÖ’ne ait uyum indekslerinin kabul edilebilir düzeyde olduğu görülmüştür. Böylelikle BSHPAAÖ’nün yapı geçerliği doğrulanabilmiştir. BSHPAAÖ'nin güvenirlik düzeyinin belirlenebilmesi için hem 5 alt boyuta hem de ölçeğin tamamına ait 
Cronbach Alpha iç tutarlılık katsayıları hesaplanmıştır. Tablo 4'te BSHPAAÖ’ye ait Cronbach Alpha iç tutarlılık katsayıları belirtilmektedir.

Tablo 4: BSHPAAÖ’ye Ait Cronbach Alpha İç Tutarlılık Katsayıları

\begin{tabular}{llc}
\hline Boyutlar & & Cronbach Alpha Değeri \\
\hline Fiziksel Boyut & (1. Boyut - 4 Madde ) &, 86 \\
Güvenirlik Boyutu & (2. Boyut - 5 Madde) &, 87 \\
Heveslilik Boyutu & (3. Boyut - 4 Madde) &, 81 \\
Güven Boyutu & (4. Boyut - 4 Madde) &, 87 \\
Empati Boyutu & (5. Boyut - 4 Madde) & 89 \\
Toplam & &, 95 \\
\hline
\end{tabular}

Tablo 4'te belirtilen değerler Özdamar (1997)'1n Cronbach Alpha iç tutarlılık katsayısının değerlendirilme aralıklarına göre BSHPAAÖ’nün yüksek derecede güvenilir olduğunu göstermektedir. $\mathrm{Bu}$ bulgulara ek olarak BSHPAAÖ’nün güvenirliğinin tekrar değerlendirilebilmesi için iki yarı test tekniği de kullanılmıştır. İki yar test sonuçlarına ait değerler ölçeğin birinci bölümü için .91 ve ikinci bölümü için .93 olarak belirlenmiştir. Bu değerler de BSHPAAÖ'nün yüksek derecede güvenilir olduğunu ortaya koymaktadır.

\section{Veri Analizi}

Veri analizi sürecinde istatistik paket programları kullanılmıştır. Öncelikle veri toplama aracının geçerliği ve güvenirliği sınanmış ve daha sonra ise verilerin hangi analiz türü ile incelenebileceğine karar verebilmek için gerekli olan normallik kontrolü (ortalama-mod-medyan, çarpıklık-basıklık değerleri, Q-Q Plot, Box Plot, Histogram grafikleri ve Kolmogorov-Smirnov ile Shapiro-Wilk normallik testleri), varyans homojenliği kontrolü (Levene testi) gerçekleştirilmiştir. Verilerin normal dağıldığını belirtebilmek için alanyazında çarpıklık-basıklık değerlerinin -1 ile +1 arasında ve Kolmogorov-Smirnov ve Shapiro-Wilk normallik testi değerlerinin $(p>, 05)$ olması gerektiğine vurgu yapılmaktadır (Büyüköztürk, Çokluk \& Köklü, 2010; Mertler \& Vannatta, 2005). Bunun yanında varyans homojenliğinin kontrolü için uygulanan Levent test değerinin de ( $p>, 05)$ olması gerekmektedir (Can, 2014; Pallant, 2017; Taşgın \& Korucuk, 2019). Araştırma verileri kontrolünde dağılım grafikleri, ortalama-modmedyan değerleri incelenmiş ve normalliği bozan bir durum ile karşılaşılmamıştır. Bunun yanında dağglıma ait çarpıklık-basıklık değerleri -1 ile +1 arasında olduğu görülmüştür. Son olarak ise veriler normallik ve homojenlik testleri ile sınanmış ve test sonuçları Tablo 5 'te sunulmaktadır.

Tablo 5: BSHPAAÖ’ne Ait Normallik ve Levene Test Değerleri

\begin{tabular}{llcccccccc}
\hline \multirow{2}{*}{ Boyutlar } & \multicolumn{3}{c}{ Kolmogorov - Smirnov } & \multicolumn{3}{c}{ Shapiro - Wilk } & \multicolumn{3}{c}{ Levene Test Değeri } \\
\cline { 2 - 9 } & İstatistik & $\mathrm{Sd}$ & $\mathrm{p}$ & İstatistik & $\mathrm{Sd}$ & $\mathrm{p}$ & $\mathrm{df1}$ & $\mathrm{df2}$ & Sig \\
\hline Fiziksel Boyut &, 110 & 523 &, 052 &, 861 & 523 &, 051 & 5 & 517 &, 052 \\
Güvenirlik Boyutu &, 065 & 523 &, 073 &, 875 & 523 &, 069 & 5 & 517 &, 180 \\
Heveslilik Boyutu &, 072 & 523 &, 062 &, 788 & 523 &, 068 & 5 & 517 &, 063 \\
Güven Boyutu &, 082 & 523 &, 056 &, 684 & 523 &, 082 & 5 & 517 &, 087 \\
Empati Boyutu &, 099 & 523 &, 053 &, 724 & 523 &, 075 & 5 & 517 &, 125 \\
Ölçek Tamamı &, 077 & 523 &, 062 &, 869 & 523 &, 058 & 5 & 517 &, 164 \\
\hline
\end{tabular}


Tablo 5 incelendiğinde Kolmogorov-Smirnov ile Shapiro-Wilk normallik test değerlerinin $(p>, 05)$ olarak tespit edildiği ve dolayısıyla dağılımın normal dağıldığına karar verilmiştir. Levene test değerinin de $(p>, 05)$ olarak belirlenmesi varyansların homojen dağıldığını ifade etmektedir. Bu bulgular ışığında verilerin parametrik teknikler ile analiz edilmesine olanak veren varsayımların karşılandığ 1 sonunca ulaşılmıştır. Bu sebeple araştırma verileri frekans analizi, bağımsız örneklem t-testi ve tek yönlü varyans analizi (ANOVA) ile analiz edilmiştir.

\section{Bulgular}

Çalışmanın bu kısmında elde edilen bulgulara yer verilmiştir. Bunun yanında ulaşılan bulgular ile araştırma problemi açıklanmış ve hipotezler sınanmıştır.

\section{Araştırma Probleminin Çözümlenmesi}

Çalışmanın ilk problemi olan "Tüketicilerin bankacılık sektöründeki hizmet pazarlaması algıları ne düzeydedir?" cevaplanabilmesi için BSHPAAÖ ile elde edilen veriler değerlendirilmiş ve ölçeğin 5 alt boyutu ile tamamına ait ortalama ve standart sapma değerleri analiz edilmiştir.

Tablo 6: BSHPAAÖ’ne Ait İstatistikler

\begin{tabular}{lcccc}
\hline Alt Boyutlar & n & $\bar{X}$ & ss & Değeri \\
\hline Fiziksel Boyut & 523 & 3,74 &, 85 & Olumlu (Yüksek) \\
Güvenirlik Boyutu & 523 & 3,81 &, 79 & Olumlu (Yüksek) \\
Heveslilik Boyutu & 523 & 3,68 &, 83 & Olumlu (Yüksek) \\
Güven Boyutu & 523 & 3,84 &, 90 & Olumlu (Yüksek) \\
Empati Boyutu & 523 & 3,36 &, 98 & Orta \\
\hline TOPLAM & 351 & 3,69 &, 73 & Olumlu (Yüksek)
\end{tabular}

Tablo 6'da BSHPAAÖ alt boyutlarına ve tamamına ait tanımlayıcı istatistiki veriler gösterilmektedir. Buna göre; Fiziksel alt boyutu ( $\overline{\mathrm{X}}=3.74$, ss=.85), Güvenirlik alt boyutu ( $\overline{\mathrm{X}}$ $=3.81, \mathrm{ss}=.79$ ), Heveslilik alt boyutu ( $\bar{X}=3.68, \mathrm{ss}=.83$ ), Güven alt boyutu ( $\bar{X}=3.84, \mathrm{ss}=.90)$ ve ölçeğin tamamı ( $\bar{X}=3.69$, ss=.73) ile yüksek "olumlu” değer aralığında yer alırken; Empati alt boyutu ( $\overline{\mathrm{X}}=3.36, \mathrm{ss}=.98$ ) ile "orta" değer aralığında yer almaktadır.

\section{Araştırma Hipotezleri $\left(\mathrm{H}_{1}, \mathrm{H}_{2}, \mathbf{H}_{6}\right.$ ve $\left.\mathbf{H}_{8}\right)$ Doğrultusunda Ulaşılan Bulgular}

Araştırma hipotezleri olan " $\mathrm{H}_{1}$ : Bankacılık sektöründe hizmet pazarlaması algıs1 tüketicilerin cinsiyetlerine göre farklılaşmaktadır.", " $\mathrm{H}_{2}$ : Bankacılık sektöründe hizmet pazarlaması algısı tüketicilerin medeni durumlarına göre farklılaşmaktadır.", "H6: Bankacılık sektöründe hizmet pazarlaması algısı tüketicilerin en çok işlem yaptıkları bankaya göre farklılaşmaktadır." ve "H : Bankacılık sektöründe hizmet pazarlaması algısı tüketicilerin en çok kullandıkları bankacılık türüne göre farklılaşmaktadır.”ın sınanabilmesi ve değişkenler arasındaki farklılığın ortaya çıkartılabilmesi için bağımsız örneklem t testi uygulanmıştır. Test sonuçları Tablo 7'de gösterilmektedir. 
Tablo 7: $\mathrm{H}_{1}, \mathrm{H}_{2}, \mathrm{H}_{6}$ ve $\mathrm{H}_{8}$ 'e Yönelik Bağımsız Örneklem T Testi Sonuçları

\begin{tabular}{|c|c|c|c|c|c|c|c|c|c|}
\hline & Alt Boyutlar & Değişken & $\mathbf{n}$ & $\bar{X}$ & ss. & sd. & $\mathbf{t}$ & p & Levene (Sig) \\
\hline \multirow{10}{*}{ 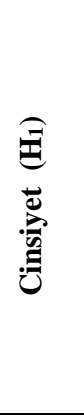 } & \multirow{2}{*}{ Fiziksel Boyut } & Kadın & 212 & 3,79 & ,76 & \multirow{2}{*}{521} & \multirow{2}{*}{,971 } & \multirow{2}{*}{,002* } & \multirow{2}{*}{, 522} \\
\hline & & Erkek & 311 & 3,51 & ,91 & & & & \\
\hline & \multirow{2}{*}{ Güvenirlik Boyutu } & Kadın & 212 & 3,87 &, 75 & \multirow{2}{*}{521} & \multirow{2}{*}{1,459} & \multirow{2}{*}{, 145} & \multirow{2}{*}{,451 } \\
\hline & & Erkek & 311 & 3,77 & ,82 & & & & \\
\hline & \multirow{2}{*}{ Heveslilik Boyutu } & Kadın & 212 & 3,72 & ,77 & \multirow{2}{*}{521} & \multirow{2}{*}{,898 } & \multirow{2}{*}{,369 } & \multirow{2}{*}{,082 } \\
\hline & & Erkek & 311 & 3,65 & ,87 & & & & \\
\hline & \multirow{2}{*}{ Güven Boyutu } & Kadın & 212 & 3,89 &, 87 & \multirow{2}{*}{521} & \multirow{2}{*}{1,120} & \multirow{2}{*}{, 263} & \multirow{2}{*}{,200 } \\
\hline & & Erkek & 311 & 3,80 & ,91 & & & & \\
\hline & \multirow{2}{*}{ Empati Boyutu } & Kadın & 212 & 3,72 & ,95 & \multirow{2}{*}{521} & \multirow{2}{*}{1,256} & $001 *$ & 122 \\
\hline & & Erkek & 311 & 3,41 & 1,00 & & & ,001 &, 122 \\
\hline & Fiziksel Bovut & Evli & 229 & 3,71 & ,83 & 521 & - 910 & 363 & \\
\hline & F1ziksel Boyut & Bekâr & 294 & 3,77 & ,877 & 321 &,- 910 & ,563 & ,415 \\
\hline$\Xi$ & & Evli & 229 & 3,81 & ,789 & & & & \\
\hline$\Xi$ & Guvenirıк Boyutu & Bekâr & 294 & 3,81 &, 80 & 521 &,- 112 & ,911 & ,448 \\
\hline$\underline{E}$ & & Evli & 229 & 3,64 &, 82 & & & & \\
\hline$\underline{\underline{a}}$ & Hevesill1k Boyutu & Bekâr & 294 & 3,71 & ,84 & 521 &,- 999 & , 318 & ,96/ \\
\hline ప & & Evli & 229 & 3,81 & ,92 & & & & 423 \\
\hline 苞 & Guven Boyutu & Bekâr & 294 & 3,86 & ,88 & 521 & -585 & 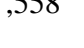 & ,423 \\
\hline & & Evli & 229 & 3,49 & ,97 & 521 & 586 & 558 & 836 \\
\hline & Empat Boyutu & Bekâr & 294 & 3,44 & ,98 & 521 & (580 & 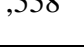 & , 850 \\
\hline & Fiziksel Bovut & Şube & 277 & 3,81 & 82 & 521 & 2.001 & $.001 *$ & 178 \\
\hline & & İnternet & 246 & 3,41 & ,88 & & & & \\
\hline$\Xi$ & Güvenirlik Boyutu & Şube & 277 & 3,85 & ,76 & 521 & 1.322 & $.036 *$ & 316 \\
\hline 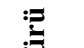 & & İnternet & 246 & 3,56 & ,83 & & & & \\
\hline 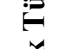 & Heveslilik Boyutu & Şube & 277 & 3,70 & ,77 & 521 & 834 & 404 & 269 \\
\hline 兰 & Hevesmin воуй & İnternet & 246 & 3,64 & ,89 & 521 & ,854 & , 404 & \\
\hline ت्ञ & Güven Boyutu & Şube & 277 & 3,89 & ,89 & 521 & 1.461 & .022 & 624 \\
\hline $\bar{E}$ & & İnternet & 246 & 3,58 & ,89 & 521 & & & \\
\hline & Empati Boyutu & Şube & 277 & 3,82 & ,96 & 521 & 1.478 & $.001 *$ & 101 \\
\hline & & İnternet & 246 & 3,39 & ,99 & 521 & & & \\
\hline & Fiziksel Bovut & Kamu & 325 & 3,73 & ,84 & 521 & 551 & 581 & 400 \\
\hline $\bar{\Xi}$ & FIZIKSeI DOyut & Özel & 198 & 3,77 & ,88 & 521 & .531 & .501 & , 400 \\
\hline$\stackrel{\infty}{\Xi}$ & Güvenirlik Boyutu & Kamu & 325 & 3,79 & ,76 & 521 & 1262 & $.046 *$ & 066 \\
\hline$\frac{5}{2}$ & GuvenIIIK Doyutu & Özel & 198 & 3,44 & ,84 & 321 & 1.202 & .040 & , \\
\hline$\stackrel{2}{\pi}$ & Heveslilik Bovutu & Kamu & 325 & 3,68 &, 82 & 521 & 035 & 972 & 984 \\
\hline & & Özel & 198 & 3,68 &, 86 & 521 & (03J & & ,904 \\
\hline$\stackrel{0}{\varrho}$ & Güven Bovputu & Kamu & 325 & 3,83 & ,90 & 521 & 072 & $027 *$ & 872 \\
\hline 뜽 & Guveri Doy dita & Özel & 198 & 3,44 & ,89 & 321 & (0) & & , \\
\hline$=$ & Empati Boyutu & Kamu & 325 & 3,47 & ,98 & 521 & .277 & .782 & 693 \\
\hline ta & & Özel & 198 & 3,44 & ,98 & (2) & & & \\
\hline
\end{tabular}

* $p<0,05$ düzeyinde anlamlıllk gösteren değer.

Tablo 7'de tüketicilerin cinsiyetleri ile BSHPAAÖ'nin fiziksel ve empati alt boyutları arasında istatistiksel olarak anlamlı düzeyde farklılıklar tespit edilmiştir. Fiziksel alt boyutta kadın tüketicilerin ortalamaları ( $\overline{\mathrm{X}}=3,79, \mathrm{ss}=.76$ ) ile erkek tüketicilerin ortalamaları $(\overline{\mathrm{X}}=3,51, \mathrm{ss}=.91$ ) arasında kadın tüketiciler lehine istatistiksel olarak anlamlı düzeyde bir fark olduğu tespit

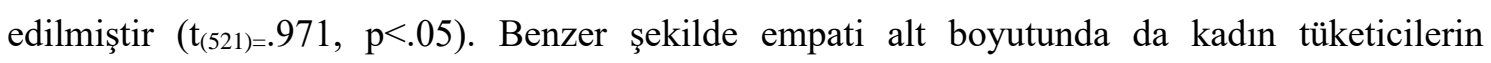
ortalamaları ( $\bar{X}=3,72, \mathrm{ss}=.95)$ ile erkek tüketicilerin ortalamaları ( $\bar{X}=3,41, \mathrm{ss}=1.00)$ arasında kadın tüketiciler lehine istatistiksel olarak anlamlı düzeyde bir fark bulunmuştur $\left(t_{(521)}=1.256\right.$, 
$\mathrm{p}<.05)$. Ancak tüketicilerin cinsiyetleri ile diğer alt boyutlar olan güvenirlik $\left(\mathrm{t}_{(521)}=1.459, \mathrm{p}>.05\right)$,

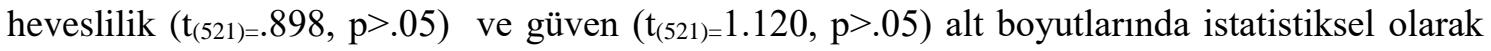
anlamlı düzeyde bir farka rastlanamamıştır.

Tüketicilerin en çok kullandıkları bankacılık türü ile BSHPAAÖ'nin fiziksel, güvenirlik, güven ve emapti alt boyutları arasında istatistiksel olarak anlamlı düzeyde farkl11ıklar belirlenmiştir. Fiziksel alt boyutta şubeyi tercih eden tüketicilerin ortalamaları ( $\overline{\mathrm{X}}=3,81, \mathrm{ss}=.82$ ) ile interneti tercih eden tüketicilerin ortalamaları ( $\overline{\mathrm{X}}=3,41, \mathrm{ss}=.88$ ) arasında şubeyi tercih eden tüketiciler lehine istatistiksel olarak anlamlı düzeyde bir fark olduğu tespit edilmiştir $\left(\mathrm{t}_{(521)}=2.001\right.$, $\mathrm{p}<.05)$. Güvenirlik alt boyutunda şubeyi tercih eden tüketicilerin ortalamaları $(\bar{X}=3,85, \mathrm{ss}=.76)$ ile interneti tercih eden tüketicilerin ortalamaları ( $\bar{X}=3,56, \mathrm{ss}=.83$ ) arasında şubeyi tercih eden tüketiciler lehine istatistiksel olarak anlamlı düzeyde bir fark olduğu tespit edilmiştir $\left(\mathrm{t}_{(521)}=1.322\right.$, $\mathrm{p}<.05)$. Benzer şekilde güven alt boyutunda şubeyi tercih eden tüketicilerin ortalamaları $(\bar{X}$ $=3,89, \mathrm{ss}=.89)$ ile interneti tercih eden tüketicilerin ortalamaları ( $\overline{\mathrm{X}}=3,58, \mathrm{ss}=.89)$ arasında şubeyi tercih eden tüketiciler lehine istatistiksel olarak anlamlı düzeyde bir fark olduğu tespit edilmiştir $\left(\mathrm{t}_{(521)}=1.461, \mathrm{p}<.05\right)$. Empati alt boyutunda da şubeyi tercih eden tüketicilerin ortalamaları ( $\overline{\mathrm{X}}$ $=3,82, \mathrm{ss}=.96)$ ile interneti tercih eden tüketicilerin ortalamaları $(\bar{X}=3,39, \mathrm{ss}=.99)$ arasında şubeyi tercih eden tüketiciler lehine istatistiksel olarak anlamlı düzeyde bir fark olduğu tespit edilmiştir $\left(\mathrm{t}_{(521)}=1.478, \mathrm{p}<.05\right)$. Ancak tüketicilerin en çok kullandıkları bankacılık türü ile heveslilik alt boyutu arasında istatistiksel olarak anlamlı düzeyde bir farka rastlanamamıştır $\left(\mathrm{t}_{(521)}=.834, \mathrm{p}>.05\right)$.

Tüketicilerin en çok tercih ettikleri banka türü ile BSHPAAÖ’nin güvenirlik ve güven alt boyutları arasında istatistiksel olarak anlamlı düzeyde farklılıklar belirlenmiştir. Güvenirlik alt boyutunda kamu bankalarını tercih eden tüketicilerin ortalamaları $(\bar{X}=3,79$, ss $=.76)$ ile özel bankaları tercih eden tüketicilerin ortalamaları $(\overline{\mathrm{X}}=3,44, \mathrm{ss}=.84)$ arasında kamu bankalarını tercih eden tüketiciler lehine istatistiksel olarak anlamlı düzeyde bir fark olduğu tespit edilmiştir

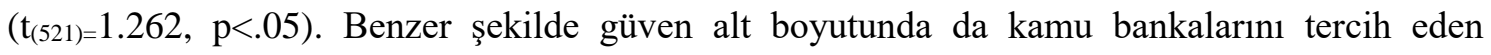
tüketicilerin ortalamaları ( $\overline{\mathrm{X}}=3,83$, ss=.90) ile özel bankaları tercih eden tüketicilerin ortalamaları ( $\overline{\mathrm{X}}=3,44, \quad \mathrm{ss}=.89$ ) arasında kamu bankalarını tercih eden tüketiciler lehine

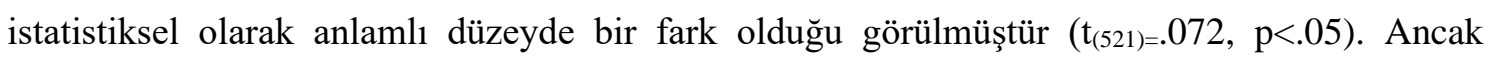

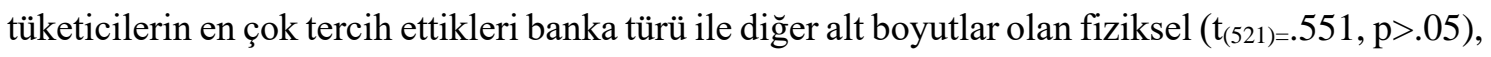

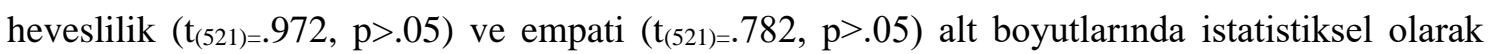
anlamlı düzeyde bir farka rastlanamamıştır. Diğer taraftan tüketicilerin medeni durumları ile

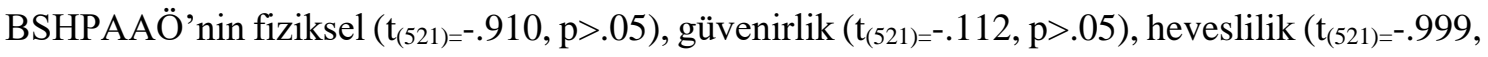

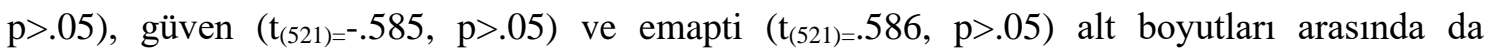
istatistiksel olarak anlamlı düzeyde bir farka rastlanamamıştır. 


\section{Araştırma Hipotezi $\left(\mathbf{H}_{3}\right)$ Doğrultusunda Ulaşılan Bulgular}

Araştırma hipotezi olan " $\mathrm{H}_{3}$ : Bankacılık sektöründe hizmet pazarlamas1 alg1s1 tüketicilerin yaşlarına göre farklılaşmaktadır."ın sınanabilmesi ve değişkenler arasındaki farklılığın ortaya çıkartılabilmesi için veriler tek yönlü varyans analizi ile test edilmiştir. Test sonuçları Tablo 8'de gösterilmektedir.

Tablo 8: Н3’eYönelik Tek Yönlü Varyans Analizi Sonuçları

\begin{tabular}{|c|c|c|c|c|c|c|c|c|c|c|c|}
\hline \multirow{2}{*}{ Alt Boyutlar } & \multirow{2}{*}{ Değişken } & \multirow{2}{*}{$\mathbf{n}$} & \multirow{2}{*}{$\bar{X}$} & \multirow{2}{*}{ ss. } & \multirow{2}{*}{$\begin{array}{l}\text { Kare } \\
\text { Ort. }\end{array}$} & \multirow{2}{*}{$\mathbf{F}$} & \multirow{2}{*}{$\mathbf{p}$} & \multirow{2}{*}{ Fark } & \multicolumn{3}{|c|}{ Levene Testi } \\
\hline & & & & & & & & & df1 & df2 & Sig \\
\hline \multirow{6}{*}{$\begin{array}{c}\text { Fiziksel } \\
\text { Boyut }\end{array}$} & $18-25$ yaş (1) & 99 & 3,62 & ,88 & & \multirow{6}{*}{4,11} & \multirow{6}{*}{, $001 *$} & \multirow{6}{*}{$\begin{array}{l}6>1, \\
6>2\end{array}$} & \multirow{6}{*}{5} & \multirow{6}{*}{517} & \multirow{6}{*}{,062 } \\
\hline & $26-33$ yaş (2) & 113 & 3,52 & 86 & ,71 & & & & & & \\
\hline & $34-41$ yaş (3) & 86 & 3,83 & 70 & & & & & & & \\
\hline & $41-48(4)$ & 51 & 3,75 & 1,05 & & & & & & & \\
\hline & $48-55(5)$ & 81 & 3,83 &, 75 & 2,92 & & & & & & \\
\hline & $55+(6)$ & 93 & 3,99 &, 83 & & & & & & & \\
\hline \multirow{6}{*}{$\begin{array}{c}\text { Güvenirlik } \\
\text { Boyutu }\end{array}$} & $18-25$ yaş (1) & 99 & 3,70 &, 80 & & \multirow{6}{*}{2,70} & \multirow{6}{*}{, $020 *$} & \multirow{6}{*}{$\begin{array}{l}6>1, \\
6>2\end{array}$} & \multirow{6}{*}{5} & \multirow{6}{*}{517} & \multirow{6}{*}{, 180} \\
\hline & $26-33$ yaş (2) & 113 & 3,72 &, 83 & ,61 & & & & & & \\
\hline & $34-41$ yaş (3) & 86 & 3,84 & ,74 & & & & & & & \\
\hline & $41-48(4)$ & 51 & 3,80 & ,96 & & & & & & & \\
\hline & $48-55(5)$ & 81 & 3,82 & 68 & 1,67 & & & & & & \\
\hline & $55+(6)$ & 93 & 4,05 &, 71 & & & & & & & \\
\hline \multirow{6}{*}{$\begin{array}{l}\text { Heveslilik } \\
\text { Boyutu }\end{array}$} & $18-25$ yaş (1) & 99 & 3,58 & ,82 & & \multirow{6}{*}{2,63} & \multirow{6}{*}{, $023 *$} & & & & \\
\hline & $26-33$ yaș (2) & 113 & 3,60 & ,91 & ,67 & & & & & & \\
\hline & $34-41$ yaş (3) & 86 & 3,73 &, 84 & & & & & & & \\
\hline & $41-48(4)$ & 51 & 3,77 &, 85 & & & & $6>2$ & 5 & 517 & ,077 \\
\hline & $48-55(5)$ & 81 & 3,72 & 63 & 1,78 & & & & & & \\
\hline & $55+(6)$ & 93 & 3,94 &, 82 & & & & & & & \\
\hline & $18-25$ yaş $(1)$ & 99 & 3,68 & 88 & & & & & & & \\
\hline & $26-33$ yaş (2) & 113 & 3,69 &, 82 & ,79 & & & & & & \\
\hline Güven & $34-41$ yaş (3) & 86 & 3,74 & ,93 & & & & & & & \\
\hline Boyutu & $41-48(4)$ & 51 & 3,85 & 1,13 & & 2,21 &, $047^{*}$ & $6>2$ & 5 & 517 & ,073 \\
\hline & $48-55(5)$ & 81 & 3,93 &, 79 & 1,75 & & & & & & \\
\hline & $55+(6)$ & 93 & 4,02 &, 85 & & & & & & & \\
\hline & $18-25$ yaş (1) & 99 & 3,33 & 1,03 & & & & & & & \\
\hline & $26-33$ yaş (2) & 113 & 3,56 & ,93 & ,96 & & & & & & \\
\hline Empati & $34-41$ yaş (3) & 86 & 3,41 & 1,03 & & 84 & & & & & \\
\hline Boyutu & $41-48(4)$ & 51 & 3,40 & 1,05 & &, 84 &, 519 & --- & 5 & 517 & ,082 \\
\hline & $48-55(5)$ & 81 & 3,56 &, 80 &, 81 & & & & & & \\
\hline & $55+(6)$ & 93 & 3,45 & 1,02 & & & & & & & \\
\hline
\end{tabular}

arasında istatistiksel olarak anlamlı düzeyde bir farkl11ık belirlenmiştir $\left[\mathrm{F}_{(5-517)}=4.114, \mathrm{p}<.05\right]$.

Farklılığın hangi gruplar arasında olduğunun belirlenebilmesi için yapılan Tukey testi sonuçlarına göre; 55 yaş ve üzerindeki tüketicilerin ortalamaları $(\bar{X}=3.99$, ss $=.83)$ ile 18-25 ( $\bar{X}=3.62$, ss $=.88)$ ve $26-33(\bar{X}=3.52, \mathrm{ss}=.86)$ yaşındaki tüketicilerin ortalamaları arasında 55 yaş ve üzerindeki tüketiciler lehine istatistiksel olarak anlamlı düzeyde bir farklılık tespit edilmiştir.

Tüketicilerin yaşları ile güvenirlik alt boyutu arasında da istatsitiksel olarak anlamlı düzeyde bir farklılık belirlenmiştir $\left[\mathrm{F}_{(5-517)}=2.708, \mathrm{p}<.05\right]$. Farkl11ı̆̆ın hangi gruplar arasında olduğunun belirlenebilmesi için yapılan Tukey testi sonuçlarına göre; 55 yaş ve üzerindeki tüketicilerin ortalamaları ( $\bar{X}=4.05, \mathrm{ss}=.71)$ ile $18-25(\bar{X}=3.70, \mathrm{ss}=.80)$ ve $26-33(\bar{X}=3.72$, $\mathrm{ss}=.83$ ) yaşındaki tüketicilerin ortalamaları arasında 55 yaş ve üzerindeki tüketiciler lehine istatistiksel olarak anlamlı düzeyde bir farklılık tespit edilmiştir. 
Benzer bulgulara heveslilik alt boyutunda da ulaşılmış ve tüketicilerin yaşları ile heveslilik alt boyutu arasında da istatsitiksel olarak anlamlı düzeyde bir farklılık belirlenmiştir $\left[\mathrm{F}_{(5-517)}=2.639, \mathrm{p}<.05\right]$. Farklılığın tespit edilebilmesi için yapılan Tukey testi sonuçlarına göre; 55 yaş ve üzerindeki tüketicilerin ortalamaları ( $\bar{X}=3.94, \mathrm{ss}=.82)$ ile $18-25(\bar{X}=3.58, \mathrm{ss}=.82)$ ve 26-33 ( $\overline{\mathrm{X}}=3.60, \mathrm{ss}=.91$ ) yaşındaki tüketicilerin ortalamaları arasında 55 yaş ve üzerindeki tüketiciler lehine istatistiksel olarak anlamlı düzeyde bir farklılık tespit edilmiştir.

Tüketicilerin yaşları ile güven alt boyutu arasında da istatsitiksel olarak anlamlı düzeyde bir farklılık belirlenmiştir $\left[\mathrm{F}_{(5-517)}=2.217, \mathrm{p}<.05\right]$. Yapılan Tukey testi sonuçlarına göre; 55 yaş ve üzerindeki tüketicilerin ortalamaları ( $\overline{\mathrm{X}}=4.02, \mathrm{ss}=.85)$ ile $18-25$ ( $\overline{\mathrm{X}}=3.68, \mathrm{ss}=.88)$ ve $26-33$ ( $\overline{\mathrm{X}}$ $=3.69, \mathrm{ss}=.82$ ) yaşındaki tüketicilerin ortalamaları arasında 55 yaş ve üzerindeki tüketiciler lehine istatistiksel olarak anlamlı düzeyde bir farklılık tespit edilmiştir. Ancak tüketicilerin yaşları ile empati alt boyutu arasında istatistiksel olarak anlamlı düzeyde bir farklılık bulunamamıştır $\left[\mathrm{F}_{(5-}\right.$ $517)=.844, \mathrm{p}>.05]$.

\section{Araştırma Hipotezi (H4) Doğrultusunda Ulaşılan Bulgular}

Araştırma hipotezi olan " $\mathrm{H}_{4}$ : Bankacılık sektöründe hizmet pazarlaması algısı tüketicilerin öğrenim durumlarına göre farklılaşmaktadır"1n sınanabilmesi ve değişkenler arasındaki farklılığın ortaya çıkartılabilmesi için veriler tek yönlü varyans analizi ile test edilmiştir. Test sonuçları Tablo 9' da gösterilmektedir.

Tablo 9: $\mathrm{H}_{4}$ 'eYönelik Tek Yönlü Varyans Analizi Sonuçları

\begin{tabular}{|c|c|c|c|c|c|c|c|c|c|c|c|}
\hline \multirow{2}{*}{ Alt Boyutlar } & \multirow{2}{*}{ Değișken } & \multirow{2}{*}{$\mathbf{n}$} & \multirow{2}{*}{$\bar{X}$} & \multirow{2}{*}{ Ss. } & \multirow{2}{*}{$\begin{array}{l}\text { Kare } \\
\text { Ort. }\end{array}$} & \multirow{2}{*}{$\mathbf{F}$} & \multirow{2}{*}{$\mathbf{p}$} & \multirow{2}{*}{ Fark } & \multicolumn{3}{|c|}{ Levene Test } \\
\hline & & & & & & & & & df1 & df2 & Sig \\
\hline \multirow{5}{*}{ Fiziksel Boyut } & İlköğretim (1) & 57 & 3,66 & ,99 & & \multirow{5}{*}{,412 } & \multirow{5}{*}{, 800} & \multirow{5}{*}{----} & \multirow{5}{*}{4} & \multirow{5}{*}{518} & \multirow{5}{*}{,078 } \\
\hline & Ortaöğretim (2) & 49 & 3,79 & 60 &, 73 & & & & & & \\
\hline & Önlisans (3) & 211 & 3,77 & ,94 & \multirow{3}{*}{, 30} & & & & & & \\
\hline & Lisans (4) & 134 & 3,70 & 79 & & & & & & & \\
\hline & Lisansüstü (5) & 72 & 3,81 & 69 & & & & & & & \\
\hline \multirow{5}{*}{$\begin{array}{c}\text { Güvenirlik } \\
\text { Boyutu }\end{array}$} & İlköğretim (1) & 57 & 3,57 & ,98 & \multirow{2}{*}{,63 } & \multirow{5}{*}{, 581} & \multirow{5}{*}{, $000 *$} & \multirow{5}{*}{$\begin{array}{l}5>1 \\
5>2\end{array}$} & \multirow{5}{*}{4} & \multirow{5}{*}{518} & \multirow{5}{*}{, 062} \\
\hline & Ortaöğretim (2) & 49 & 3,65 &, 54 & & & & & & & \\
\hline & Önlisans (3) & 211 & 3,78 &, 84 & & & & & & & \\
\hline & Lisans (4) & 134 & 3,97 &, 80 & \multirow[t]{2}{*}{, 36} & & & & & & \\
\hline & Lisansüstü (5) & 72 & 3,98 &, 56 & & & & & & & \\
\hline \multirow{5}{*}{$\begin{array}{c}\text { Heveslilik } \\
\text { Boyutu }\end{array}$} & İlköğretim (1) & 57 & 3,73 & ,86 & \multirow{2}{*}{,68 } & \multirow{5}{*}{, 712} & & & & & \\
\hline & Ortaöğretim (2) & 49 & 3,79 &, 70 & & & & & & & \\
\hline & Önlisans (3) & 211 & 3,63 & ,86 & & &, 584 & ---- & 4 & 518 & , 191 \\
\hline & Lisans (4) & 134 & 3,65 &, 85 & ,49 & & & & & & \\
\hline & Lisansüstü (5) & 72 & 3,76 &, 70 & & & & & & & \\
\hline & İlköğretim (1) & 57 & 3,69 & 1,16 & & & & & & & \\
\hline & Ortaöğretim (2) & 49 & 3,64 &, 74 &, 79 & & & & & & \\
\hline Güven Boyutu & Önlisans (3) & 211 & 3,81 & 87 & & 1,789 & ,036* & $\begin{array}{l}5>1, \\
5>2\end{array}$ & 4 & 518 &, 141 \\
\hline & Lisans (4) & 134 & 3,78 & ,92 & 1,42 & & & & & & \\
\hline & Lisansüstü (5) & 72 & 4,05 & 67 & & & & & & & \\
\hline & İlköğretim (1) & 57 & 3,33 & 1,29 & 04 & & & & & & \\
\hline & Ortaöğretim (2) & 49 & 3,29 & 69 & ,94 & & & & & & \\
\hline Empati Boyutu & Önlisans (3) & 211 & 3,42 & 1,00 & & 2,795 &, $026 *$ & $\begin{array}{l}5>1, \\
5>2\end{array}$ & 4 & 518 & ,084 \\
\hline & Lisans (4) & 134 & 3,44 & ,91 & 2,65 & & & & & & \\
\hline & Lisansüstü (5) & 72 & 3,63 & ,86 & & & & & & & \\
\hline
\end{tabular}


Tablo 9'da tüketicilerin öğrenim durumları ile BSHPAAÖ’nin güvenirlik alt boyutu arasında istatistiksel olarak anlamlı düzeyde bir fark olduğu görülmüştür $\left[\mathrm{F}_{(4-518)}=.581, \mathrm{p}<.05\right]$. Farklılığın hangi gruplar arasında olduğunun belirlenebilmesi için Tukey testi yapılmıştır. Test sonuçlarına göre; Lisansüstü mezunu tüketicilerin ortalamaları ( $\overline{\mathrm{X}}=3.98, \mathrm{ss}=.56)$ ile ilköğretim ( $\overline{\mathrm{X}}=3.57, \mathrm{ss}=.98)$ ve ortaöğretim ( $\overline{\mathrm{X}}=3.65, \mathrm{ss}=.54)$ mezunu tüketicilerin ortalamaları arasında lisansüstü mezunu tüketiciler lehine istatistiksel olarak anlamlı düzeyde bir farklılık tespit edilmiştir. Tüketicilerin öğrenim durumları ile güven alt boyutu arasında da istatsitiksel olarak anlamlı düzeyde bir fark olduğu görülmüştür $\left[\mathrm{F}_{(4-518)}=1.789, \mathrm{p}<.05\right]$. Grup içi farkların belirlenebilmesi için yapılan Tukey testi sonuçlarına göre; Lisansüstü mezunu tüketicilerin ortalamaları ( $\overline{\mathrm{X}}=4.05, \mathrm{ss}=.67)$ ile ilköğretim $(\overline{\mathrm{X}}=3.69$, ss=1.16) ve ortaöğretim $(\overline{\mathrm{X}}=3.64$, ss=.74) mezunu tüketicilerin ortalamaları arasında lisansüstü mezunu tüketiciler lehine istatistiksel olarak anlamlı düzeyde bir farklılık olduğu görülmüştür. Benzer farka empati alt boyutunda da ulaşılmıştır $\left[\mathrm{F}_{(4-518)}=2.795, \mathrm{p}<.05\right]$. Yapılan Tukey testi sonucunda; Lisansüstü mezunu tüketicilerin ortalamaları $(\bar{X}=3.63$, ss $=.86)$ ile ilköğretim $(\bar{X}=3.33$, ss=1.29) ve ortaögretim ( $\bar{X}=3.26$, ss=.69) mezunu tüketicilerin ortalamaları arasında lisansüstü mezunu tüketiciler lehine istatistiksel olarak anlamlı düzeyde bir farklılık olduğu tespit edilmiştir. Ancak tüketicilerin öğrenim durumları ile BSHPAAÖ'nin fiziksel $\left[\mathrm{F}_{(4-518)}=.412, \mathrm{p}>.05\right]$ ve heveslilik $\left[\mathrm{F}_{(4-518)}=.712, \mathrm{p}>.05\right]$ alt boyutları arasında istatistiksel olarak anlamlı düzeyde bir fark bulunamamıştır.

\section{Araştırma Hipotezi $\left(\mathrm{H}_{7}\right)$ Doğrultusunda Ulaşılan Bulgular}

Araştırma hipotezi olan " $\mathrm{H}_{7}$ : Bankacılık sektöründe hizmet pazarlaması alg1s1 tüketicilerin banka ile en çok yaptıkları işlem türüne göre farklılaşmaktadır"ın sınanabilmesi ve değişkenler arasındaki farklılığın ortaya çıkartılabilmesi için veriler tek yönlü varyans analizi ile test edilmiştir. Test sonuçları Tablo 10'da gösterilmektedir.

Tablo 10: $\mathrm{H}_{7}$ 'yeYönelik Tek Yönlü Varyans Analizi Sonuçları

\begin{tabular}{|c|c|c|c|c|c|c|c|c|c|c|c|}
\hline \multirow{2}{*}{$\begin{array}{c}\text { Alt } \\
\text { Boyutlar }\end{array}$} & \multirow{2}{*}{ Değişken } & \multirow{2}{*}{$\mathbf{n}$} & \multirow{2}{*}{$\bar{X}$} & \multirow{2}{*}{ ss. } & \multirow{2}{*}{$\begin{array}{l}\text { Kare } \\
\text { Ort. }\end{array}$} & \multirow{2}{*}{$\mathbf{F}$} & \multirow{2}{*}{$\mathbf{p}$} & \multirow{2}{*}{ Fark } & \multicolumn{3}{|c|}{ Levene Test } \\
\hline & & & & & & & & & df1 & df 2 & Sig \\
\hline $\begin{array}{c}\text { Fiziksel } \\
\text { Boyut }\end{array}$ & $\begin{array}{l}\text { ParaYat-Çek (1) } \\
\text { Transfer (2) } \\
\text { K. K. İssl. (3) } \\
\text { Kredi Kull. (4) } \\
\text { Maaş İşl. (5) }\end{array}$ & $\begin{array}{c}314 \\
46 \\
44 \\
60 \\
59 \\
\end{array}$ & $\begin{array}{l}3,83 \\
3,63 \\
3,88 \\
3,40 \\
3,62 \\
\end{array}$ & $\begin{array}{c}, 81 \\
, 74 \\
, 79 \\
, 94 \\
1,00 \\
\end{array}$ &, 714 & 4,13 & ,003* & $\begin{array}{l}1>4 \\
3>4\end{array}$ & 4 & 518 & ,211 \\
\hline $\begin{array}{l}\text { Güvenirlik } \\
\text { Boyutu }\end{array}$ & $\begin{array}{l}\text { ParaYat-Çek (1) } \\
\text { Transfer (2) } \\
\text { K. K. İssl. (3) } \\
\text { Kredi Kull. (4) } \\
\text { Maaş İşl. (5) }\end{array}$ & $\begin{array}{c}314 \\
46 \\
44 \\
60 \\
59 \\
\end{array}$ & $\begin{array}{l}3,86 \\
3,72 \\
4,05 \\
3,60 \\
3,69 \\
\end{array}$ & $\begin{array}{l}, 75 \\
, 67 \\
, 70 \\
, 95 \\
, 90 \\
\end{array}$ & 2,078 & 3,36 &, $010 *$ & $3>4$ & 4 & 518 & ,058 \\
\hline $\begin{array}{c}\text { Heveslilik } \\
\text { Boyutu }\end{array}$ & $\begin{array}{l}\text { ParaYat-Çek (1) } \\
\text { Transfer (2) }\end{array}$ & $\begin{array}{c}314 \\
46 \\
\end{array}$ & $\begin{array}{l}3,74 \\
3,60\end{array}$ & $\begin{array}{l}, 80 \\
, 72 \\
\end{array}$ & ,669 & 4,35 &, $002 *$ & $\begin{array}{l}1>4 \\
3>4\end{array}$ & 4 & 518 & ,428 \\
\hline
\end{tabular}




\begin{tabular}{|c|c|c|c|c|c|c|c|c|c|c|c|}
\hline \multirow{6}{*}{$\begin{array}{c}\text { Alt } \\
\text { Boyutlar }\end{array}$} & \multirow{2}{*}{ Değişken } & \multirow{2}{*}{$\mathbf{n}$} & \multirow{2}{*}{$\bar{X}$} & \multirow{2}{*}{ ss. } & \multirow{2}{*}{$\begin{array}{l}\text { Kare } \\
\text { Ort. }\end{array}$} & \multirow{5}{*}{$\mathbf{F}$} & \multirow{5}{*}{$\mathbf{p}$} & \multirow{5}{*}{ Fark } & \multicolumn{3}{|c|}{ Levene Test } \\
\hline & & & & & & & & & df1 & df2 & Sig \\
\hline & K. K. İşl. (3) & 44 & 3,82 &, 80 & & & & & & & \\
\hline & Kredi Kull. (4) & 60 & 3,31 & .78 & 2,913 & & & & & & \\
\hline & Maaş İşl. (5) & 59 & 3,72 &, 98 & & & & & & & \\
\hline & ParaYat-Çek (1) & 314 & 3,90 & ,87 & & \multirow{5}{*}{2,11} & \multirow{5}{*}{,078 } & \multirow{5}{*}{--- } & \multirow{5}{*}{4} & \multirow{5}{*}{518} & \multirow{5}{*}{,070 } \\
\hline \multirow{4}{*}{$\begin{array}{l}\text { Güven } \\
\text { Boyutu }\end{array}$} & Transfer (2) & 46 & 3,63 &, 73 & , 195 & & & & & & \\
\hline & K. K. İş1. (3) & 44 & 3,96 &, 85 & & & & & & & \\
\hline & Kredi Kull. (4) & 60 & 3,70 &, 90 & 1,680 & & & & & & \\
\hline & Maaş İşl. (5) & 59 & 3,67 & 1,09 & & & & & & & \\
\hline \multirow{5}{*}{$\begin{array}{l}\text { Empati } \\
\text { Boyutu }\end{array}$} & ParaYat-Çek (1) & 314 & 3,62 & ,95 & 949 & \multirow{5}{*}{2,77} & \multirow{5}{*}{,056 } & \multirow{5}{*}{---} & \multirow{5}{*}{4} & \multirow{5}{*}{518} & \multirow{5}{*}{,362 } \\
\hline & Transfer (2) & 46 & 3,08 &, 90 & 949 & & & & & & \\
\hline & K. K. İşl. (3) & 44 & 3,54 & 1,09 & & & & & & & \\
\hline & Kredi Kull. (4) & 60 & 3,36 & 1,00 & 2,635 & & & & & & \\
\hline & Maas İsl. (5) & 59 & 3,51 & 1.01 & & & & & & & \\
\hline
\end{tabular}

Tablo 10'da tüketicilerin banka ile en çok yaptıkları işlem türü ile BSHPAAÖ'nin fiziksel alt boyutu arasında istatistiksel olarak anlamlı düzeyde bir farklılık belirlenmiştir $\left[\mathrm{F}_{(4-518)}=4.138\right.$, $\mathrm{p}<.05]$. Farklılığın hangi gruplar arasında olduğunun belirlenebilmesi için yapılan Tukey testi sonuçlarına göre; banka ile en çok yaptığı işlem türü para yatırma-çekme olan tüketicilerin ortalamaları ( $\bar{X}=3.83, \mathrm{ss}=.81)$ ile en çok yaptı̆̆ 1 işlem türü kredi kullanımı ( $\overline{\mathrm{X}}=3.40, \mathrm{ss}=.94)$ olan tüketicilerin ortalamaları arasında en çok yaptığı işlem türü para yatırma-çekme olan tüketiciler lehine istatistiksel olarak anlamlı düzeyde bir farklılık olduğu tespit edilmiştir. Benzer şekilde fiziksel alt boyutta en çok yaptı̆̆ işlem türü kredi kartı işlemleri olan tüketicilerin ortalamaları ( $\overline{\mathrm{X}}=3.88, \mathrm{ss}=.79$ ) ile en çok yaptı̆̆ 1 işlem türü kredi kullanımı ( $\overline{\mathrm{X}}=3.40$, ss=.94) olan tüketicilerin ortalamaları arasında en çok yaptığı işlem türü kredi kartı işlemleri olan tüketiciler lehine istatistiksel olarak anlamlı düzeyde bir farkl1lık olduğu görülmüştür. Tüketicilerin banka ile en çok yaptıkları işlem türü ile güvenirlik alt boyutunda da istatistiksel olarak anlamlı düzeyde bir farkl11ı tespit edilmiştir $\left[\mathrm{F}_{(4-518)}=3.365, \mathrm{p}<.05\right]$. Yapılan Tukey testi sonucunda en çok yaptığı işlem türü kredi kartı işlemleri olan tüketicilerin ortalamaları ( $\overline{\mathrm{X}}=4.05$, ss=.70) ile en çok yaptığ i işlem türü kredi kullanımı $(\bar{X}=3.60, \mathrm{ss}=.95)$ olan tüketicilerin ortalamaları arasında en çok yaptığı işlem türü kredi kartı işlemleri olan tüketiciler lehine istatistiksel olarak anlamlı düzeyde bir farklılık olduğu belirlenmiştir. Tüketicilerin banka ile en çok yaptıkları işlem türü ile heveslilik alt boyutu arasında istatistiksel olarak anlamlı düzeyde bir farklılık belirlenmiştir $\left[\mathrm{F}_{(4-518)}=4.355, \mathrm{p}<.05\right]$. Farklılığın hangi gruplar arasında olduğunun belirlenebilmesi için yapılan Tukey testi sonuçlarına göre; banka ile en çok yaptığ işlem türü para yatırma-çekme olan tüketicilerin ortalamaları $(\overline{\mathrm{X}}=3.74, \mathrm{ss}=.80)$ ile en çok yaptı̆̆ $\breve{g}_{1}$ işlem türü kredi kullanımı ( $\overline{\mathrm{X}}=3.31, \mathrm{ss}=.78$ ) olan tüketicilerin ortalamaları arasında en çok yaptığ yatırma-çekme olan tüketiciler lehine istatistiksel olarak anlamlı düzeyde bir farkl1lık olduğu tespit edilmiştir. Benzer şekilde fiziksel alt boyutta en çok yaptığı işlem türü kredi kartı işlemleri olan tüketicilerin ortalamaları ( $\overline{\mathrm{X}}=3.82, \mathrm{ss}=.80)$ ile en çok yaptığ 
=3.31, ss=.78) olan tüketicilerin ortalamaları arasında en çok yaptı̆̆ 1 işlem türü kredi kartı işlemleri olan tüketiciler lehine istatistiksel olarak anlamlı düzeyde bir farklılık olduğu tespit edilmiştir. Ancak tüketicilerin banka ile en çok yaptıkları işlem türü ile güven $\left[\mathrm{F}_{(4-518)}=2.112\right.$, $\mathrm{p}>.05]$ ve empati $\left[\mathrm{F}_{(4-518)}=2.778, \mathrm{p}>.05\right]$ alt boyutları arasında istatistiksel olarak anlamlı düzeyde bir farklılığa rastlanamamıştır.

\section{Tartışma, Sonuç ve Öneriler}

Tüketicilerin bankacılık sektöründeki hizmet pazarlama algısı düzeylerinin belirlenmesi ve bu alg1 düzeylerinin tüketicilerin demografik özelliklere göre farklılaşma durumlarının incelenmesinin amaçlandığı bu çalışmada örneklemin yarısından fazlasının cinsiyetinin erkek, medeni durumunun bekâr olduğu; şube bankacılığını kullanmayı tercih eden ve 41 yaş altı bireylerden oluştuğu görülmektedir. Bunun yanında örneklemin yaklaşık 3'te 2'sinin önlisans ve lisans mezunu, 3000TL ve altı bir gelire sahip, en çok kamu bankalarını tercih eden, en fazla para yatırma-çekme işlemi yapan bireylerden oluştuğu ön plana çıkmaktadır.

Araştırma probleminin "Tüketicilerin bankacılık sektöründeki hizmet pazarlaması algıları ne düzeydedir?" çözümlenebilmesi için yapılan analizler sonucunda tüketicilerin fiziksel alt boyutu, güvenirlik alt boyutu, heveslilik alt boyutu, güven alt boyutu ve ölçeğin tamamı yüksek "olumlu" değer aralığında yer alırken; empati alt boyutu "orta” değer aralığında yer almaktadır. $\mathrm{Bu}$ bulgular ile tüketicilerin bankacılık sektöründeki hizmet pazarlaması algılarının genel olarak yüksek düzeyde olduğu sonucuna ulaşılabilir. Ancak tüketicilerin bankacılık sektörü unsurlanı (çalışan, yönetici, şirket vb.) ile orta düzeyde empati kurabildiği görülmüştür. Benzer bulgulara Demirtaş (2019)'da da rastlanmış ve tüm alt boyutlar yüksek "olumlu” değer aralığında yer almıştır. Demirtaş'ın (2019) farklılaştığı nokta ise empati alt boyutunda olmuştur. Bu çalışmada "orta" değer aralığında bulunan yer alan empati alt boyutu Demirtaş'ın araştırmasında diğer alt boyutlar gibi yüksek "olumlu” değer aralığında yer almıştır.

Birinci araştırma hipotezi olan " $\mathrm{H}_{1}$ : Bankacılık sektöründe hizmet pazarlaması algısı tüketicilerin cinsiyetlerine göre farklılaşmaktadır"ın sınanabilmesi için yapılan istatistik testler sonucunda; tüketicilerin cinsiyetleri ile BSHPAAÖ'nin fiziksel ve empati alt boyutları arasında kadın tüketiciler lehine istatistiksel olarak anlamlı düzeyde fark tespit edilmiştir. Başka bir ifadeyle kadın tüketicilerin bankacılık sektörü fiziksel yapısına ve bankacılık sektörü unsurlarına (çalışan, yönetici, şirket vb.) yönelik tutum düzeylerinin erkek tüketicilerin sahip oldukları tutum düzeylerinden anlamlı derecede daha yüksek olduğu sonucuna ulaşılmıştır. Ancak Çiftçi (2006) ve Eroğluer (2013) tarafından yapılan çalışmada cinsiyet değişkenine göre hizmet kalitesi algısında anlamlı düzeyde bir farklılığa rastlanamamıştır. Cinsiyet değişkeni kapsamında ulaşılan bir diğer araştırma sonucu ise tüketicilerin cinsiyetleri ile güvenirlik, heveslilik ve güven alt boyutlarında istatistiksel olarak anlamlı düzeyde bir farka rastlanamamış olmasıdır. 
İkinci araştırma hipotezinin " $\mathrm{H}_{2}$ : Bankacılık sektöründe hizmet pazarlamas1 alg1s1 tüketicilerin medeni durumlarına göre farklılaşmaktadır” çözümlenebilmesi için yapılan bağımsız örneklem $\mathrm{t}$ testi sonucuna göre; tüketicilerin medeni durumları ile bankacıllk sektörü hizmet pazarlaması algı düzeyleri (tüm alt boyutlarda) arasında istatistiksel olarak anlamlı düzeyde bir farka rastlanamamıştır. Bu bulgular tüketicilerin bankacılık sektörü hizmet pazarlaması alg1 düzeylerinin medeni durumlarına göre farklılaşmadığı sonucunu ortaya koymaktadır. Araştırmada ulaşılan sonuçtan farklı olarak Eroğluer (2013) medeni durum değişkeni ile hizmet kalitesi algısı arasında anlamlı düzeyde farklılıklara rastlamıştır.

Üçüncü araştırma hipotezinin " $\mathrm{H}_{3}$ : Bankacılık sektöründe hizmet pazarlamas1 algıs1 tüketicilerin yaşlarına göre farklılaşmaktadır” sınanabilmesi için tek yönlü varyans analizi yapılmıştır. Analiz sonucunda; tüketicilerin yaşları ile BSHPAAÖ’nin fiziksel, güvenirlik, heveslilik ve güven alt boyutu arasında istatistiksel olarak anlamlı düzeyde bir fark olduğu sonucuna ulaşılmıştır. Grup içi farklılıkların tespit edilebilmesi için yapılan Tukey testi sonuçlarına göre; fark bulunan tüm alt boyutlarda 55 yaş ve üzerindeki tüketicilerin ortalamaları ile 18-25 ve 26-33 yaşındaki tüketicilerin ortalamaları arasında 55 yaş ve üzerindeki tüketiciler lehine istatistiksel olarak anlamlı düzeyde bir farklılık belirlenmiştir. Ancak tüketicilerin yaşları ile empati alt boyutu arasında istatistiksel olarak anlamlı düzeyde bir farklılık bulunamamıştır. Yaşlı tüketicilerin (55 yaş ve üzeri) bankacılık sektörü hizmet pazarlaması algı düzeylerinin genç tüketicilerin (18-25 ve 26-33 yaş) sahip olduğu alg1 düzeyinden daha yüksek olduğu sonucuna ulaşılmıştır. Diğer bir ifadeyle yaşlı tüketicilerin bankacılık sektörüne ait fiziksel, güvenirlik, heveslilik ve güven boyutlarında gençlere oranla daha yüksek bir algı düzeyine sahip olduğu görülmüştür. Benzer sonuçlara Eroğluer (2013) de ulaşmış ve tüketicilerin yaşları ile hizmet kalitesi algıları arasında anlamlı düzeyde farklılıklar olduğunu ortaya koymuştur. Ancak Çiftçi (2006) araştırmasında tüketicilerin yaşları ile hizmet kalitesi algıları arasında anlamlı düzeyde bir farka rastlamamıştır.

Dördüncü araştırma hipotezinin " $\mathrm{H}_{4}$ : Bankac1lık sektöründe hizmet pazarlaması algıs1 tüketicilerin öğrenim durumlarına göre farklılaşmaktadır" çözümlenebilmesi için yapılan analizler sonucunda tüketicilerin öğrenim durumları ile BSHPAAÖ’nin güvenirlik, güven ve empati alt boyutları arasında istatistiksel olarak anlamlı düzeyde bir fark olduğu görülmüştür. Grup içi farklılıkların tespit edilebilmesi için yapılan Tukey testi sonuçlarına göre; fark bulunan tüm alt boyutlarda lisansüstü mezunu tüketicilerin ortalamaları ile ilköğretim ve ortaöğretim mezunu tüketicilerin ortalamaları arasında lisansüstü mezunu tüketiciler lehine istatistiksel olarak anlamlı düzeyde bir farkl11ık tespit edilmiştir. Lisansüstü mezunu öğrenciler bankacılık sektörü hizmet pazarlaması algı düzeylerinin güvenirlik, güven ve empati boyutunda ilköğretim ve ortaöğretim mezunu tüketicilerden daha yüksek olduğu tespit edilmiştir. Diğer bir ifadeyle 
lisansüstü diplomaya sahip tüketicilerin bankacılık sektörü hizmet pazarlamasında güvenirlik ve güven ile empati kurmaya yönelik alg1 düzeylerinin ilköğretim ve ortaöğretim mezunu tüketicilerden daha yüksek olduğu sonucuna ulaşılmıştır. Benzer sonuçlara Çiftçi (2006) da ulaşmış ve tüketicilerin öğrenim durumları ile hizmet kalitesi algıları arasında anlamlı düzeyde farklılıklar olduğunu ortaya koymuştur. Bunun yanında tüketicilerin öğrenim durumları ile BSHPAAÖ'nin fiziksel ve heveslilik alt boyutları arasında istatistiksel olarak anlamlı düzeyde bir fark bulunamamıştır.

Beşinci araştırma hipotezinin " $\mathrm{H}_{5}$ : Bankac1lık sektöründe hizmet pazarlaması algıs1 tüketicilerin gelir düzeylerine göre farklılaşmaktadır" sınanabilmesi için tek yönlü varyans analizi yapılmıştır. Analiz sonucunda; tüketicilerin gelir düzeleri ile bankacılık sektörü hizmet pazarlaması algı düzeyleri (tüm alt boyutlarda) arasında istatistiksel olarak anlamlı düzeyde bir farka rastlanamamıştır. Bu bulgular tüketicilerin bankacılık sektörü hizmet pazarlaması algı düzeylerinin gelirlerine göre farklılaşmadığı sonucunu ortaya koymaktadır.

Altıncı araştırma hipotezinin " $\mathrm{H}_{6}$ : Bankacılık sektöründe hizmet pazarlaması algıs1 tüketicilerin en çok işlem yaptıkları bankaya göre farklılaşmaktadır” çözümlenebilmesi için yapılan analizler sonucunda; tüketicilerin en çok işlem yaptıkları banka ile BSHPAAÖ’nin güvenirlik ve güven alt boyutları arasında kamu bankalarını tercih eden tüketiciler lehine istatistiksel olarak anlamlı düzeyde bir fark olduğu görülmüsştür. Kamu bankalarını tercih eden tüketicilerin güven ve güvenirlik boyutunda özel bankaları tercih eden tüketicilerden daha yüksek bir algı düzeyine sahip olduğu sonucuna ulaşılmıştır. Başka bir ifadeyle kamu bankalarını tercih eden tüketiciler bankalarına yönelik güven düzeylerinin özel bankaları tercih eden tüketicilerden daha yüksek olduğu söylenebilir. Ancak tüketicilerin en çok tercih ettikleri banka türü ile diğer alt boyutlar olan fiziksel, heveslilik ve empati alt boyutlarında istatistiksel olarak anlamlı düzeyde bir farka rastlanamamıştır. Tüketiciler özellikle bankacılık sektörü hizmet pazarlaması alg1 düzeylerinin güven ve güvenirlik boyutunda kamu bankalarını özel bankalardan daha yüksek düzey olarak belirtmişlerdir.

Yedinci araştırma hipotezinin " $\mathrm{H}_{7}$ : Bankacılık sektöründe hizmet pazarlaması alg1s1 tüketicilerin banka ile en çok yaptıkları işlem türüne göre farklılaşmaktadır" sınanabilmesi için tek yönlü varyans analizi yapılmıştır. Analiz sonucunda; tüketicilerin banka ile en çok yaptıkları işlem türü ile BSHPAAÖ'nin fiziksel ve heveslilik alt boyutları arasında istatistiksel olarak anlamlı düzeyde farklılıklar belirlenmiştir. Grup içi farkl1lıkların tespit edilebilmesi için yapılan Tukey testi sonuçlarına göre; fiziksel ve heveslilik alt boyutlarında banka ile en çok yaptığı işlem türü para yatırma-çekme olan tüketiciler ve kredi kartı işlemleri olan tüketicilerin ortalamaları ile en çok yaptığı işlem türü kredi kullanımı olan tüketicilerin ortalamaları arasında en çok yaptığ 1 işlem türü para yatırma-çekme ve kredi kartı işlemleri olan tüketiciler lehine istatistiksel olarak 
anlamlı düzeyde bir farklılık olduğu tespit edilmiştir. Başka bir ifadeyle en çok yaptığı işlem türü para yatırma-çekme ve kredi kartı işlemleri olan tüketicilerin fiziksel ve heveslilik boyutunda bankacılık sektörü hizmet pazarlaması algı düzeylerinin en çok yaptı̆̆ işlem türü kredi kullanımı olan tüketicilerden daha yüksek olduğu sonunca varılmıştır. Benzer bir sonuca güvenirlik boyutunda ulaşılmış ve en çok yaptığı işlem türü kredi kartı işlemleri olan tüketicilerin ortalamaları ile en çok yaptığı işlem türü kredi kullanımı olan tüketicilerin ortalamaları arasında en çok yaptığı işlem türü kredi kartı işlemleri olan tüketiciler lehine istatistiksel olarak anlamlı düzeyde bir farkl11ık olduğu belirlenmiştir. Ancak tüketicilerin banka ile en çok yaptıkları işlem türü ile güven ve empati alt boyutları arasında istatistiksel olarak anlamlı düzeyde bir farklılığa rastlanamamıştır.

Sekizinci araştırma hipotezinin " $\mathrm{H}_{8}$ : Bankacıllk sektöründe hizmet pazarlaması algıs1 tüketicilerin en çok kullandıkları bankacılık türüne göre farklılaşmaktadır" çözümlenebilmesi için yapılan analizler sonucunda; tüketicilerin en çok kullandıkları bankacılık türü ile BSHPAAÖ’nin fiziksel, güvenirlik, güven ve emapti alt boyutları arasında şubeyi tercih eden tüketiciler lehine istatistiksel olarak anlamlı düzeyde farklılıklar belirlenmiştir. Bankacılık işlemlerinde en çok şubeyi kullanan tüketicilerin fiziksel, güvenirlik, güven ve empati boyutlarında sahip oldukları hizmet pazarlaması alg1 düzeylerinin internet bankacılı̆̆ını tercih eden tüketicilerin sahip oldukları hizmet pazarlaması algı düzeylerinden anlamlı şekilde daha yüksek olduğu sonucuna ulaşılmıştır. Ancak tüketicilerin en çok kullandıkları bankacılık türü ile heveslilik alt boyutu arasında istatistiksel olarak anlamlı düzeyde bir farka rastlanamamıştır.

$\mathrm{Bu}$ çalışmada sonuç olarak bir araştırma problemi çözümlenerek, sekiz hipotez sınanmıştır. Çalışma sonucunda altı araştırma hipotezi $\left(\mathrm{H}_{1}, \mathrm{H}_{3}, \mathrm{H}_{4}, \mathrm{H}_{6}, \mathrm{H}_{7}\right.$ ve $\left.\mathrm{H}_{8}\right)$ kabul edilirken; iki araştırma hipotezi $\left(\mathrm{H}_{2}\right.$ ve $\left.\mathrm{H}_{5}\right)$ reddedilmiştir.

$\mathrm{Bu}$ çalışmanın sonucunda aşağıdaki öneriler geliştirilmiştir:

1. Bankaların hizmet pazarlaması algı düzeylerinin tüketicilerde arttırılarak çok yüksek değer aralığına taşınabileceği uygulamalar yapması önerilebilir.

2. Bankaların tüketicilerin daha yüksek empati kurabilmelerini sağlayabilmek için banka/tüketici etkileşimini sağlayabilecek faaliyetler ile bu konuda tüketicilerde olumlu bir etki yaratması önerilebilir.

3. Bankaların erkek tüketicilerin sahip olduğu hizmet pazarlaması algı düzeylerini (fiziksel ve empati boyutunda) arttırabilecek etkinlikler (reklam, tanıtım, halkla ilişkiler faaliyetleri, promosyonlar vb. diğer kampanyalar) yürütmesi önerilebilir.

4. Genç tüketicilerin sahip oldukları bankacılık sektörü hizmet pazarlaması alg1 düzeylerinin desteklenebileceği faaliyetlerin (reklam, tanıtım, halkla ilişkiler faaliyetleri, promosyonlar vb. diğer kampanyalar) bankalar tarafindan yürütülmesi önerilebilir. 
5. İlköğretim ve ortaöğretim mezunu tüketicilerin sahip oldukları bankacılık sektörü hizmet pazarlaması alg1 düzeylerinin (güvenirlik, güven ve empati alt boyutlarında) desteklenebileceği faaliyetlerin (reklam, tanıtım, halkla ilişkiler faaliyetleri, promosyonlar vb. diğer kampanyalar) bankalar tarafindan planlanması ve uygulanması önerilebilir.

6. Özel bankaların tüketicilerin hizmet pazarlaması algı düzeylerinin güven ve güvenirlik alt boyutlarında arttırılabileceği faaliyetlerde (reklam, tanıtım, halkla ilişkiler faaliyetleri, promosyonlar vb. diğer kampanyalar) bulunması önerilebilir.

7. Bankaların en çok yaptıkları bankacılık işlemi kredi kullanımı olan tüketicilerin hizmet pazarlaması algı düzeylerinin fiziksel ve heveslilik alt boyutlarında yükseltilebilmesi için çeşitli uygulamalar (reklam, tanıtım, halkla ilişkiler faaliyetleri, promosyonlar vb. diğer kampanyalar) yapması önerilebilir.

8. Bankaların en çok yaptıkları bankacılık işlemi kredi kullanımı olan tüketicilerin hizmet pazarlaması algı düzeylerinin güvenirlik alt boyutunda yükseltilebilmesi için çeşitli faaliyetlerde (reklam, tanıtım, halkla ilişkiler faaliyetleri, promosyonlar vb. diğer kampanyalar) bulunulması önerilebilir.

9. İnternet bankacılığı faaliyetlerinin (internet ve mobil uygulamaların) tüketiciler için daha çekici hale getirilmesi önerilebilir.

10. Bankaların özellikle internet bankacıllğı faaliyetlerinde daha fazla güvenliği arttırıcı tedbirler almaları önerilebilir.

11. Bankalar tarafından personellerine hizmet pazarlaması ve etkili iletişim ile ilgili hizmet içi eğitimler uygulanması önerilebilir.

12. Bankaların sıklıkla tüketici görüşlerine başvurarak zayıf/eksik yönlerini tespit etmeleri ve böylelikle zayıflıkların/eksikliklerin giderilmesi önerilebilir.

13. Bankaların tüketicilerin kendilerini özel hissedecekleri uygulamalar (özel günlerde hediyeler, mesaj göndilmesi ve aranması ile kişisel danışmanların tüketicilerle periyodik iletişim kurması vb.) yürütmesi önerilebilir.

14. Bu araştırma 2019 yılında Kars ilinde yapılmıştır. Bu sebeple benzer çalışmaların farklı zamanlarda ve farklı şehirlerde yürütülmesi ile derinlemesine analizler yapılabilmesi için nitel veya karma yöntemli araştırmaların yapılması da önerilebilir.

\section{Kaynakça}

Assets, (2019). https://assets.kpmg/, (Erişim Tarihi: 12.12.19).

Bankacılık Düzenleme ve Denetleme Kurumu, (2019). https://www.bddk.org.tr/, (Erişim Tarihi: 12.12.19).

Büyüköztürk, Ş., Çokluk, Ö., \& Köklü, N. (2010). Sosyal Bilimler İçin İstatistik. Ankara: Pegem Akademi.

Büyüköztürk, Ş., Çakmak, E. K., Akgün, Ö. E., Karadeniz, Ş. \& Demirel, F. (2017). Bilimsel Araştırma Yöntemleri (23. Basım). Ankara: Pegem Akademi.

Can, A. (2014). SPSS İle Bilimsel Araştırma Sürecinde Nicel Veri Analizi (3. Basım). Ankara: Pegem akademi. 
Critensen, B. L., Johnson, R. B. \& Turner, L. A. (2015). Research Methods, Design And Analysis (12th Edition). Harlow: Rearson Education Limited.

Çiftçi, A. G. (2006). Hizmet kalitesi ve bankacılık sektöründe hizmet kalitesi ölçümüne yönelik bir uygulama, Yayınlanmış Yüksek Lisans Tezi. Dokuz Eylül üniversitesi, Sosyal Bilimler Enstitüsü, İşletme Ana Bilim Dalı, İzmir. (Tez No. 189867).

Demirtaş, K. (2019). Hizmet pazarlamasında kalite algısının müşteri sadakatine etkisinde müşteri memnuniyetinin aracılık rolü, Yayınlanmış Yüksek Lisans Tezi. Beykent Üniversitesi, Sosyal Bilimler Enstitüsü, İşletme Yönetimi Ana Bilim Dalı, İstanbul. (Tez No. 545692).

Eroğlu, K. (2013). Hizmet kalitesi algısının kurumsal imaja etkisi üzerine hizmet sektöründe bir araştırma. Anadolu Üniversitesi Sosyal Bilimler Dergisi, 13(4), 29-46.

Fraenkel, J. R., \& Wallen, N. E. (2006). How to Design and Evaluate Research in Education (6 ${ }^{\text {th }}$ Edition). New York: McGraw-Hill.

Gliner, J. A., Morgan, G. A., \& Leech, N. L. (2015). Uygulamada Araştırma Yöntemleri Desen ve Analizi Bütünleştiren Yaklaşım (2. Basım). (Çev. Ed: S. Turan), Ankara: Nobel Yayınevi.

Güven, M., \& Çelik, N. (2007). Analitik hiyerarşi süreci yöntemi ile otel işletmelerinde hizmet kalitesini değerlendirme: Bartın Örneği. ZKÜ Sosyal Bilimler Dergisi, 3 (6), 1-20.

Gözlü, S. (1995). Hizmet kalitesinin kontrolünde istatistiksel yöntemler. Verimlilik Dergisi, Mpm Yayını, 2, Ankara.

Hooper, D., Coughan, J., \& Mullen, M. R. (2008). Structural equation modelling: Guidelines for determining model fit. Electronic Journal Of Business Researchmethods, 6(1), 53-60.

İlhan, M., \& Çetin, B. (2014). LISREL ve AMOS programları kullanılarak gerçekleştirilen yapısal eşitlik modeli (YEM) analizlerine ilişkin sonuçların karşılaştırılması. Eğitimde ve Psikolojide Ölçme ve Değerlendirme Dergisi, 5(2), 26-42.

Jöreskog, K. G., \& Sörbom, D. (1996). LISREL 8 User's Reference Guide. Chicago: Scientific Software.

Kantaroğlu, B. (2018). Hizmet pazarlamasında müşteri memnuniyeti ve algılanan değerin müşteri sadakati üzerindeki etkisi: bankacılık sektöründe bir uygulama, Yayınlanmış Yüksek Lisans Tezi. Bayburt Üniversitesi, Sosyal Bilimler Enstitüsü, Bayburt (Tez No. 506458).

Kayalı, N., \& Yüksel, F. (2012). Türk bankacılık sektöründe iç denetim faaliyetlerinin uygulamalı olarak incelenmesi. Celal Bayar Üniversitesi Sosyal Bilimler Dergisi, 10(2), 162-187.

Kayapalı-Yıldırım, S., \& Ekinci, O. (2019). Siber mobbing ölçeği geçerlik ve güvenirlik çalışması. Mavi Atlas, 7(2), 294-320.

Koç, E. (2018), Hizmet Pazarlaması ve Yönetimi (3. Basım). Ankara: Seçkin Yayınevi.

Kotler, P., \& Keller, K. (2006). Marketing Management (12th Edition). Prentice Hall: Upper Saddle River.

Kuriloff, A., Hemphill, J. M., \& Cloud, D. (1993). Starting and Managing The Small Business. Singapore: Mc GrawHill Edition.

Marcoulides, G., \& Schumacher, R. (2001). New Developments and Tecniques in Structural Equation Modeling. London: Lawrence Erlbaum Associates, Publishers.

McMillan, J., \& Schumacher, S. (2014). Research in Education Evidence - Based Inquiry (7th Edition). Harlow: Rearson Education Limited.

Mertler, C. A., \& Vannatta, R. A. (2005). Advanced and Multivariate Statistical Methods: Practical Application and Interpretation (3nd Edition). United States: Pyrczak Publishing.

Muhasebe News, (2019). https://www.muhasebenews.com/, (Erişim Tarihi: 12.12.19).

Mujic, N., \& Legcevic J. (2006). Applying a multiple-item scale for measuring the quality of the medical services of primary care doctors: an exploratory study. SEE Journal, September, 115-129. 
Özdamar, K. (1997). Paket Programlar İle İstatistiksel Veri Analizi. Eskişehir: Anadolu Üniversitesi Yayınları.

Özdemir, Z. (2010). Bilanço yapısı itibarıyla Türk bankacılık sistemi. Siyaset Bilimleri Dergisi, 50, 867-899.

Pallant, J. (2017). SPSS Kullanma Kılavuzu SPSS İle Adım Adım Veri Analiz. (Çev. S. Balcı ve B. Ahi). Ankara: Anı Yayıncilik.

Punch, F. K. (2014). Sosyal Araştırmalara Giriş Nicel ve Nitel Yaklaşımlar, (Çev. D. Bayrak, H. Bader-Arslan \& Z. Akyüz). Ankara: Siyasal Kitabevi.

Savaş, H., \& Kesmez, A. (2014). Hizmet kalitesinin servqual modeli ile ölçülmesi: aile sağlığı merkezleri üzerine bir araştırma. Pamukkale Üniversitesi Sosyal Bilimler Enstitüsü Dergisi,17, 1-13.

Schumacher, R., \& Lomax, R. (2004). A Beginner's Guide to Structual Equation Modeling. London: Lawrence Erlbaum Associates, Publishers.

Seçer, İ. (2015). Psikolojik Test Geliştirme ve Uyarlama Süreci SPSS ve LISREL Uygulamaları. Ankara: Anı Yayıncilik.

Sullivan, G. M., \& Artino, A. R. (2013). Analyzing and interpreting data from likert-type scales. Journal of Graduate Medical Education, 5(4), 541-542.

Sümer, G. (2016). Türk bankacılık sektörünün tarihsel gelişimi ve AB bankacılık sektörü ile karşılaştırılması. Gazi Üniversitesi İktisadi ve İdari Bilimler Fakültesi Dergisi, 18(2), 485-508.

Taşgın, A., \& Korucuk, M. (2018). Development of foreign language lesson satisfaction scale (flss): Validity and reliability study. Journal of Curriculum and Teaching, 7(2), 66-77.

Taşgın, A., \& Korucuk, M. (2019). Meslek yüksekokulu öğrencilerinin çoklu zekâ alanlarının incelenmesi. Kuramsal Eğitimbilim Dergisi [Journal of Theoretical Educational Science], 12(2), 550-575.

Türkiye Bankalar Birliği, (2019). https://www.tbb.org.tr/, (Erişim Tarihi: 12.12.19).

Yetiz, A. (2009). Ofis mobilyaları ve ofis mobilyalarının tasarımını etkileyen ergonomi faktörünün incelenmesi Adana'da bir banka örneği, Yayımlanmamış Yüksek Lisans Tezi. Çukurova Üniversitesi, Sosyal Bilimler Enstitüsü, Adana (Tez No.230578).

Yetiz, F. (2016). Bankacılığın doğuşu ve Türk bankacılık sistemi. Niğde Üniversitesi İktisadi ve İdari Bilimler Fakültesi Dergisi, 9(2), s.107-117.

Y1ldırım, F., \& Naktiyok, S. (2017). The mediating role of organizational support in the effect of transformational leadership on employee empowerment. Polish Journal of Management Studies, 16(1), 292-303.

Yücel, N., Yücel, A., \& Atl1, Y. (2012). Belediyelerin sunduğu hizmetlerde vatandaş memnuniyeti: Elâzığ belediyesi örneği. Electronic Journal of Vocational Colleges, 2 (2), 31-41.

Yüksel, Ü., \& Mermod, A. (2004). Hizmet Pazarlaması (1. Bask1). İstanbul: Beta Yayınları. 